\title{
Impact of Corruption on Firm-Level Export Decisions
}

\author{
William W. Olney ${ }^{1}$
}

June 10, 2015

\begin{abstract}
This paper examines the impact of corruption on the self-selection of firms into domestic and export markets. A heterogeneous firm model predicts that corruption decreases the probability that a firm only sells domestically, increases the probability that a firm exports indirectly through an intermediary, and decreases the probability that a firm exports directly. The propositions of the model are tested using a comprehensive data set of over 23,000 firms in 80 developing countries. The results confirm both the self-selection of firms according to their productivity and the anticipated impact of corruption. This indicates that in developing countries where corruption is especially severe, intermediaries provide a crucial link to global markets.

Keywords: Corruption; Exports; Intermediaries

JEL Codes: F1; O1
\end{abstract}

\footnotetext{
${ }^{1}$ Department of Economics, Williams College, Williamstown, MA 01267 (email: william.w.olney@williams.edu). I am especially grateful to Ben Li. This paper also benefitted from helpful comments and suggestions from numerous seminar participants.
} 


\section{Introduction}

Corruption is one of the most significant impediments to economic growth. Numerous studies have found that corruption reduces human capital, discourages investment, leads to a misallocation of resources, lowers the quality of public infrastructure and services, and thus ultimately hampers economic development. ${ }^{2}$ However, relatively little is known about how corruption affects international trade or exporting in particular. This is important since corruption may adversely affect access to foreign markets and thus limit the gains from trade especially for less-developed countries. ${ }^{3}$ This paper fills this gap by examining the impact of corruption on the self-selection of firms into domestic, indirect export, and direct export markets using a simple heterogeneous firm model. The predictions of the model are tested using a comprehensive data set on firm-level behavior in developing countries. The results confirm that corruption does reduce the likelihood that a firm exports directly. This would be troubling except the results also indicate that corruption increases the likelihood that a firm indirectly exports through an intermediary. Thus, intermediaries provide an important link to foreign markets especially in corrupt developing countries.

Intermediaries play a crucial role in facilitating international trade. ${ }^{4}$ For instance, among developing countries, on average 29 percent of manufacturing firms export indirectly through an intermediary which accounts for 17 percent of total export sales. ${ }^{5}$ These intermediaries perform a host of important functions for manufacturers who wish to sell abroad but are reluctant to export directly themselves. For example, intermediaries often handle distributional and shipping logistics, overcome informational barriers, and deal with bureaucratic procedures (Sourdin and Pomfret 2012). While potentially quite important, this last benefit of exporting through an intermediary has not been studied and is thus the focus of this analysis. Specifically, since intermediaries repeatedly perform the tasks associated with exporting, they may have institutional knowledge, connections, and economies of scale that are useful in dealing with red tape, bribes, and corruption.

There is a large body of anecdotal evidence that indicates that intermediaries are skillful at

\footnotetext{
${ }^{2}$ See for instance Mauro 1995, Bardhan 1997, Shleifer and Vishny 1993, Fisman and Svensson 2007, and Olken and Pande 2012.

${ }^{3}$ See Frankel and Romer 1999, Dollar and Kraay 2004, Feyrer 2009a, Feyrer 2009b for evidence that trade leads to economic growth.

${ }^{4}$ See Ahn, Khandelwal, and Wei 2011, Bernard, Grazzi, and Tomasi 2013, Bernard, Jensen, Redding, and Schott 2010, Antras and Costinot 2010, Antras and Costinot 2011, Rauch and Watson 2004, Blum, Claro, and Horstmann 2010, Basker and Van 2010, Feenstra and Hanson 2004.

${ }^{5}$ Statistics calculated using the Enterprise Survey data produced by the World Bank.
} 
navigating government bureaucracies in less-developed countries. For instance, "despachantes" in Brazil, "coyotes" in Mexico, "tramitadores" in Peru, El Salvador, and other Latin American countries, and legal advisory firms in Georgia are all examples of intermediary firms whose purpose is to help people and firms deal with corruption (Fredriksson 2014, Djankov 2002). Through repeated interactions these intermediaries learn how to circumvent red tape, regulations, and bureaucracy often by relying on contacts within the government (Fredriksson 2014). Thus, these intermediaries can significantly reduce the time and cost of doing business especially in corrupt developing countries.

There is evidence that the level of corruption and the prevalence of trade intermediaries systematically vary across countries in a way that supports this hypothesis. For instance, a broad cross-country comparison confirms this important relationship between corruption and indirect exporting. Specifically, Figure 1 shows that there is a positive relationship between average corruption within a country and the share of firms that indirectly export. Certainly there are many other factors that can influence both corruption and export patterns and thus the goal of this paper is to examine to what extent corruption is causing firms to use intermediaries to access foreign markets.

Figure 1

Share of Indirect Exporters and Average Corruption

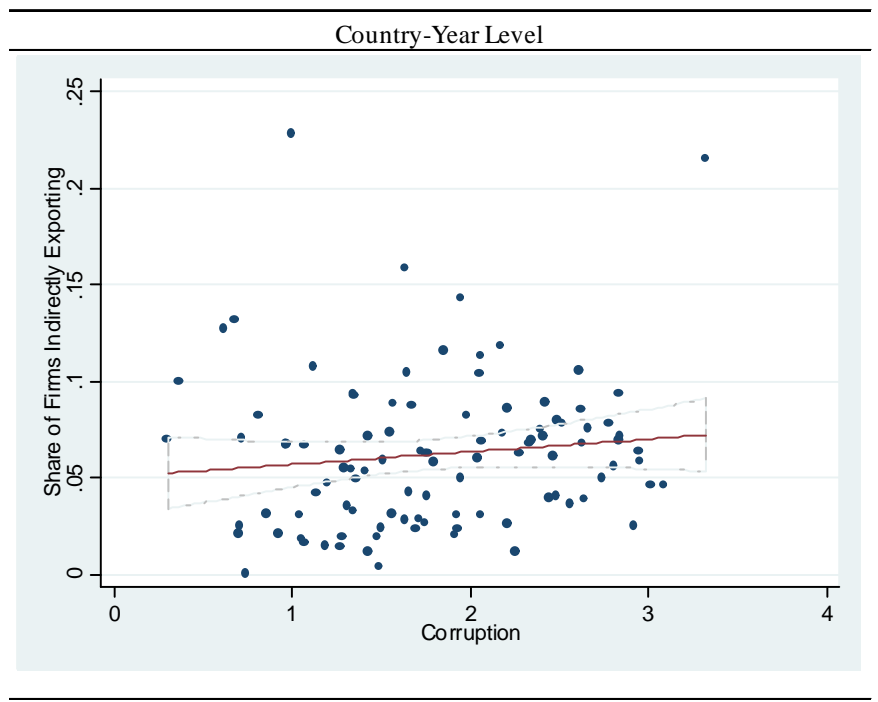

The share of indirect exporters is plotted against average corruption at the country-year level. Data from Enterprise Survey data produced by the World Bank.

A basic theoretical model clarifies these relationships and generates a number of important predictions. First, firms self-select into different modes of operation based on their productiv- 
ity. Specifically, the least productive firms sell domestically only, the more productive firms sell domestically and indirectly export through an intermediary, and the most productive firms sell domestically and export directly. Second, within this framework, the impact of corruption on the sorting of firms into these production modes is examined. Corruption reduces the profits that a domestic firm and direct exporting firm earn. However, firms that indirectly export through an intermediary are relatively insulated from corrupt officials. Thus, the productivity cutoffs for entrance into the domestic and direct export markets both increase, while the indirect export cutoff remains the same. As a result, the model predicts that corruption will decrease the probability that a firm only sells domestically, increase the probability of indirect exporting, and decrease the probability of direct exporting.

The propositions of the model are tested using the Enterprise Survey, produced by the World Bank. This is a unique firm-level data set that has information on corruption, domestic sales, indirect exports, and direct exports at the firm level. Specifically, the data set spans over 23,000 firms, 11 different sectors, 80 developing countries, and six years (2005-2010) which provides the scale and scope necessary to examine the predictions of the model. In addition, the ability to measure corruption at the firm level, represents an important improvement over other empirical studies which typically rely on country-level measures.

The estimation strategy used in this paper takes two broad approaches. First, an aggregate analysis looks at the impact of average corruption on characteristics at the country, sector, and year level. Specifically, this approach examines the impact of corruption on the number of domestic, indirect exporters, and direct exporters and on the average productivity of these different types of firms. Then, a firm-level analysis examines how corruption affects the self-selection of firms into various production modes. The benefit of this empirical strategy is that individual firm characteristics can be controlled for in addition to the unobserved factors that are constant within countries, sectors, and years. Endogeneity and measurement error concerns are addressed by using two instruments: the reported corruption level faced by other firms within the same market and bribes demanded by government officials. This IV approach alleviates the most obvious reverse causality concern that firms that indirectly export may report more corruption simply because they rely on middlemen to access foreign markets.

The results provide strong support for the assumptions and propositions of the model. First, 
the least productive firms sell domestically only, the more productive firms indirectly export, and the most productive firms directly export. With the first proposition of the model confirmed, it is then possible to examine how corruption affects the self-selection of firms into these production modes. Both the aggregate and firm-level results support the second prediction that corruption decreases the probability that a firm will only sell domestically. Given the additional costs associated with operating in a corrupt environment, only the more productive firms find it profitable to enter the market. The aggregate and firm-level results also confirm the third proposition of the model. Conditional on exporting, corruption increases the probability a firm indirectly exports and decreases the probability that a firm directly exports. This indicates that when faced with corruption some firms prefer to export through an intermediary rather than directly export themselves. These results are robust to a wide variety of different empirical specifications which provides compelling support for the propositions of the model.

More generally, these results have important policy implications for developing countries. Corruption does impose a cost on the economy in the sense that fewer firms will be able to enter the market and sell domestically. In addition, fewer firms find it profitable to directly export. In the absence of intermediaries, this would be a troubling finding since it would indicate that corruption is stifling both domestic production and international trade. However, this paper finds that intermediaries play a important role in minimizing the detrimental impact of corruption. In response to corruption, there is an important substitution away from direct exporting and towards indirect exporting. Thus, intermediaries play a crucial role in shielding manufacturing firms from corrupt officials. In developing countries where corruption is especially severe, intermediaries provide an important link to global markets.

This paper contributions to the existing literature in four important ways. First, the development literature has long recognized the adverse consequences of corruption (Mauro 1995, Bardhan 1997, Shleifer and Vishny 1993, Fisman and Svensson 2007, Olken and Pande 2012). However, there has been little attempt, as far as I know, to examine its impact on international trade. This paper fills this gap by utilizing a heterogeneous firm model to provide new insights into the implications of corruption and then tests these predictions using a comprehensive data set on firms in developing countries. Since access to foreign markets has been found to be an important determinant of growth, the impact of corruption on exporting seems especially relevant for developing country's 
growth prospects.

Second, to the best of my knowledge, this is the only paper to examine the impact of corruption on the selection of firms into domestic and export markets. While the international trade literature has recently focused on how heterogeneous firms select into different markets (Melitz 2003, Helpman 2006, Bernard et al. 2007), there has been little effort to integrate corruption into this framework. This is unfortunate given the prevalence of corruption and thus this paper attempts to fill this gap in the literature.

Third, institutional quality has been found to be an important determinant of economic performance (Acemoglu, Johnson, and Robinson 2001 and 2002). To the extent that corruption is the antithesis of good institutions, this paper is related to a larger literature that examines the relationship between institutional quality and international trade (Levchenko 2007, Nunn 2007). These studies tend to find that strong institutions give countries a comparative advantage in industries that are more reliant on institutional quality. This paper takes a different approach by focusing specifically on individual firms and how their export decisions respond to one component of institutional quality, namely corruption.

Fourth, this paper contributes to the burgeoning body of empirical research that focuses more carefully on trade intermediaries (Ahn et al. 2011, Bernard et al. 2013, Bernard et al. 2010, Blum et al. 2010, Basker and Van 2010, Feenstra and Hanson 2004). I find that intermediaries perform two important functions. They provide access to foreign markets for firms who otherwise would not be able to export on their own. In addition, this paper shows that intermediaries play a crucial role in shielding manufacturers from corrupt government officials which is a new and important finding.

The remainder of the paper is organized as follows. The next section presents the basic model and the key theoretical propositions that will be tested. Section 3 describes the empirical specification and the instruments used. The data and the descriptive statistics are discussed in Section 4. The baseline results are presented in Section 5 and Section 6 pursues a couple of extensions. Finally, Section 7 concludes. 


\section{Model}

This section outlines the theoretical framework. This basic model makes a number of simplifying assumptions in order to focus more carefully on the key relationships of interest. While the model is not the main contribution of this paper, it is appealing because it is clear and tractable, it generates useful and testable predictions, and it helps motivate the empirical analysis that follows.

Specifically, the model follows Melitz's (2003) insight that heterogeneous firms differ in terms of their productivities and that there are fixed costs of exporting. In addition to selling domestically and exporting, in this model firms also have the ability to export indirectly through an intermediary sector. This generates specific predictions on the entry of firms into the domestic, indirect export, and direct export markets according to their productivity. Then, within this framework, the impact of corruption on the self-selection of firms into these different modes of operation is examined.

\subsection{Domestic and Export Sales}

Suppose that within an industry a continuum of firms each produce a differentiated product. Following Helpman (2006), the demand function for each firm $j$ is $x_{j}=A p_{j}^{-\varepsilon}$ where $x$ is quantity, $p$ is price, $A$ is a measure of the demand level in the domestic market, and $\varepsilon$ is the demand elasticity. ${ }^{6}$ Each firm is relatively small in size and thus they treat $A$ as exogenous. The firm enters the industry and then discovers its productivity $\theta_{j}$. The firm faces variable costs of production of $c / \theta_{j}$ and fixed costs of production of $c f_{d}$ where $c$ reflects the cost of resources (i.e. the wage rate). This implies that the firm's profit maximizing price is $p_{j}=c / \alpha \theta_{j}$ which generates domestic profits of: ${ }^{7}$

$$
\pi_{d}=\Theta B-c f_{d}
$$

where $\Theta=\theta^{\varepsilon-1}, B=(1-\alpha) A(c / \alpha)^{1-\varepsilon}$, and the subscript $j$ is dropped since profits depend on productivity and not the identity of the firm.

In addition to the profits obtained from selling domestically, a firm can also directly export their good abroad. ${ }^{8}$ For simplicity, assume that the foreign country is identical to the home country and

\footnotetext{
${ }^{6}$ Specifically, $\varepsilon=1 /(1-\alpha)>1$ since $0<\alpha<1$.

${ }^{7}$ See the appendix for the formal derivation of the model.

${ }^{8}$ The model and subsequent empirical analysis do not focus on the destination market. Although interesting, this
} 
thus the demand level $A$ and the demand function $x_{j}$ are the same. However, a firm faces an additional fixed cost $\left(c f_{x}\right)$ in order to sell abroad which reflects the distribution and service costs associated with exporting. In addition, a firm faces iceberg trade costs, which means that $\tau_{x}>1$ units need to be shipped for one unit to arrive. These variable trade costs usually reflect transport costs, duties, and other impediments to exporting. Therefore, a firm that sells domestically can also earn export profits of:

$$
\pi_{x}=\tau_{x}^{1-\varepsilon} \Theta B-c f_{x}
$$

Instead of directly exporting to the foreign market, a firm can choose to indirectly export their products through an intermediary. This perfectly competitive intermediary sector purchases the goods from the manufacturers and sells these goods abroad. Indirect exporting requires the manufacturing firm to pay a fixed cost $\left(c f_{i}\right)$ in order to enjoy the services provided by the intermediary. The fixed costs associated with indirect exporting are less than those associated with directly exporting $\left(f_{i}<f_{x}\right)$, since the intermediary handles the distributional costs associated with exporting for a variety of manufacturing firms. However, a firm that chooses to indirectly export through the intermediary has to pay higher variable $\operatorname{costs}\left(\tau_{i}>\tau_{x}\right)$. These higher costs reflect the fact that the intermediary has to repackage and relabel the goods in order to sell them abroad (Ahn et al. 2011). Thus, the additional profits a firm can enjoy from exporting indirectly are:

$$
\pi_{i}=\tau_{i}^{1-\varepsilon} \Theta B-c f_{i}
$$

Figure 2 shows the profits from selling domestically, directly exporting, and indirectly exporting $\left(\pi_{d}, \pi_{x}\right.$, and $\left.\pi_{i}\right)$ as a function of the firm's productivity draw $(\theta) .{ }^{9}$ All the profit curves are increasing with the firm's productivity. However, the $\pi_{d}$ curve is steeper than the $\pi_{x}$ and $\pi_{i}$ curves due to the additional variable trade costs associated with exporting. To access the foreign market, the is not the goal of this analysis and unfortunately the Enterprise Survey data does not provide information on the destination of exports. See Ahn et al. (2011) for insight into how indirect exports depend on the characteristics of the destination market.

${ }^{9}$ Figure 2 assumes that $f_{d}<\tau_{i}^{\varepsilon-1} f_{i}<\tau_{x}^{\varepsilon-1} f_{x}$ which ensures that $\Theta_{d}<\Theta_{i}<\Theta_{x}$. 
manufacturing firm faces a trade-off. They can directly export and enjoy lower variable costs but pay higher fixed costs or they can indirectly export and enjoy lower fixed costs but pay higher variable costs. This trade-off is reflected in Figure 2, where in addition to domestic profits these more productive firms choose whether to indirectly or directly export based on which option yields higher profits.

Figure 2

Firm Productivity, Profits, and Self-Selection

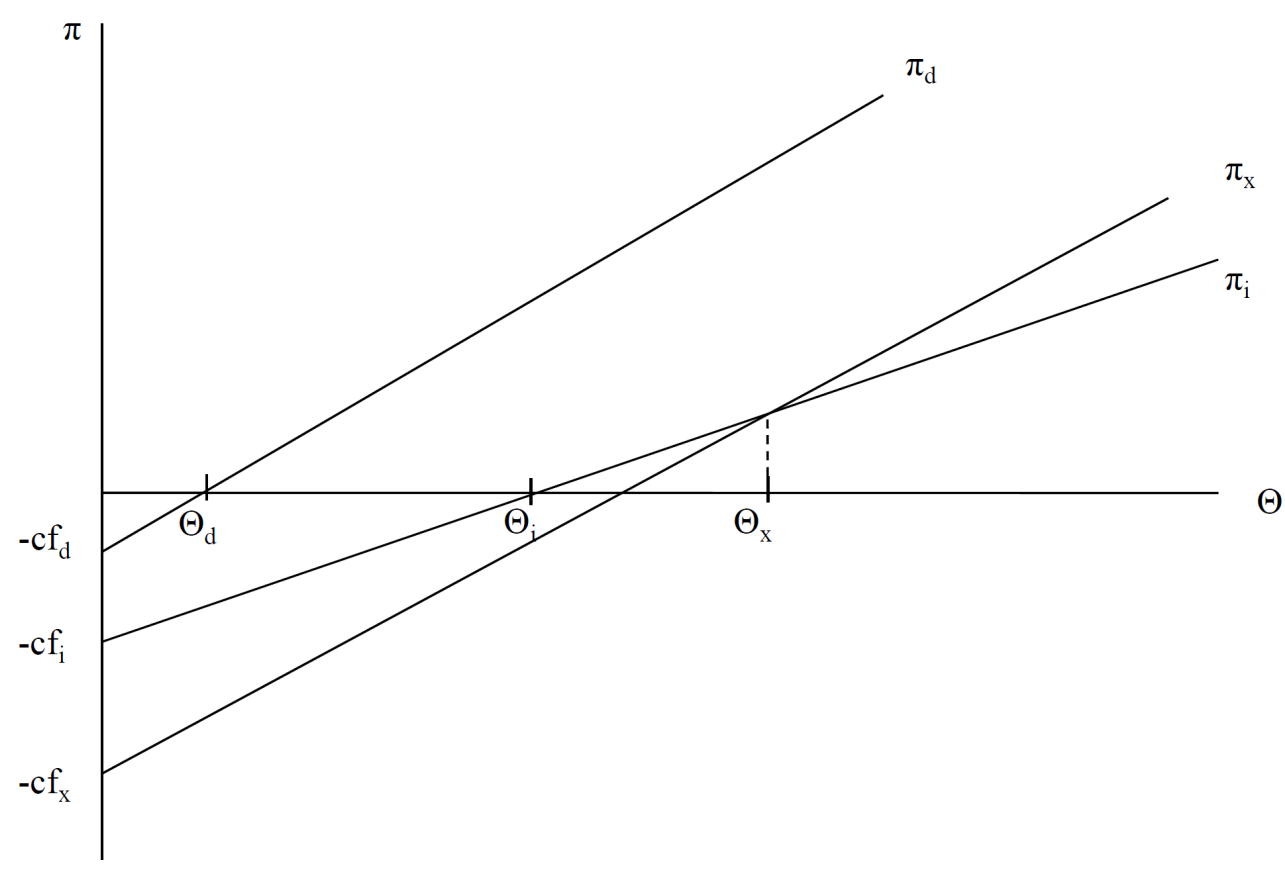

Figure 2 shows that firms sort themselves across modes according to their productivity. Firms with $\Theta<\Theta_{d}$ are not productive enough to overcome the fixed costs of producing domestically and thus they exit the market. Firms with $\Theta_{d}<\Theta$ enter the market and sell domestically. In addition, some of these firms are also able to earn positive profits from exporting. Specifically, firms with $\Theta_{i}<\Theta<\Theta_{x}$ sell domestically and also export indirectly. For these firms, accessing the foreign market through the intermediary generates positive profits that exceed those that could be earned from directly exporting themselves. Finally, firms with $\Theta_{x}<\Theta$ sell domestically and export directly. For these firms, exporting directly generates positive profits that exceed what they could earn by exporting indirectly. Thus, this theoretical framework generates the following testable prediction: 
Proposition 1 The least productive firms sell domestically only, the more productive firms sell domestically and export indirectly, and the most productive firms sell domestically and export directly.

The intermediary sector performs an important function. For firms, that otherwise could not access the foreign market due to the high fixed costs of directly exporting, the intermediary provides an opportunity for them to engage in trade. Specifically, the intermediary handles the networking and distributional fixed costs of exporting which enables lower productivity firms to export to the foreign market. However, in exchange, firms that use an intermediary incur higher variables costs. Thus, the most productive firms that are able to overcome the fixed costs are better off directly exporting themselves rather than relying on an intermediary.

\subsection{Corruption}

Intermediaries execute a variety of important trade related tasks for manufacturing firms, including dealing with government bureaucracy (Sourdin and Pomfret 2012). Since they perform these duties repeatedly for numerous different manufacturing firms, this should generate institutional knowledge, connections, and economies of scale that allow them to complete these tasks with greater efficiency and at lower cost. Most importantly for this analysis, intermediaries should be more adept at navigating the red tape, bribes, and corruption prevalent in many developing countries. In contrast, these impediments are more onerous for firms that sell domestically or choose to directly export themselves, since they do not have the expertise or connections necessary to circumvent government bureaucracy and corrupt officials. Thus, the model assumes that indirect export profits are less affected by corruption than domestic or direct export profits. As discussed previously, anecdotal evidence (and ultimately the empirical results of this paper) provides support for this assumption. For example, in Chile in 2006, which had relatively little corruption, only 6 percent of all firms and 20 percent of exporters indirectly exported through an intermediary. However, in Columbia in 2006, where corruption is much more problematic, 12 percent of all firms and 43 percent of exporters indirectly exported. ${ }^{10}$

Suppose that corruption imposes an additional variable cost of $\gamma>1$ on domestic firms and on direct exporting firms. ${ }^{11}$ Thus, corruption reduces profits from domestic sales to:

\footnotetext{
${ }^{10}$ Statistics calculated using the Enterprise Survey data produced by the World Bank.

${ }^{11}$ As shown in section 8.4 of the appendix, the implications are similar if instead it is assumed that corruption
} 


$$
\pi_{d}^{\prime}=\gamma^{1-\varepsilon} \Theta B-c f_{d}
$$

and reduces profits from directly exporting to:

$$
\pi_{x}^{\prime}=\gamma^{1-\varepsilon} \tau_{x}^{1-\varepsilon} \Theta B-c f_{x}
$$

However, the profits $\left(\pi_{i}\right)$ associated with indirectly exporting are unaffected. ${ }^{12}$ Thus, as seen in Figure 3, the profit curves associated with domestic sales and with direct exports will both rotate down but the profit curve associated with indirect exports remains the same.

Figure 3

Impact of Corruption on Firm Profits and Self-Selection

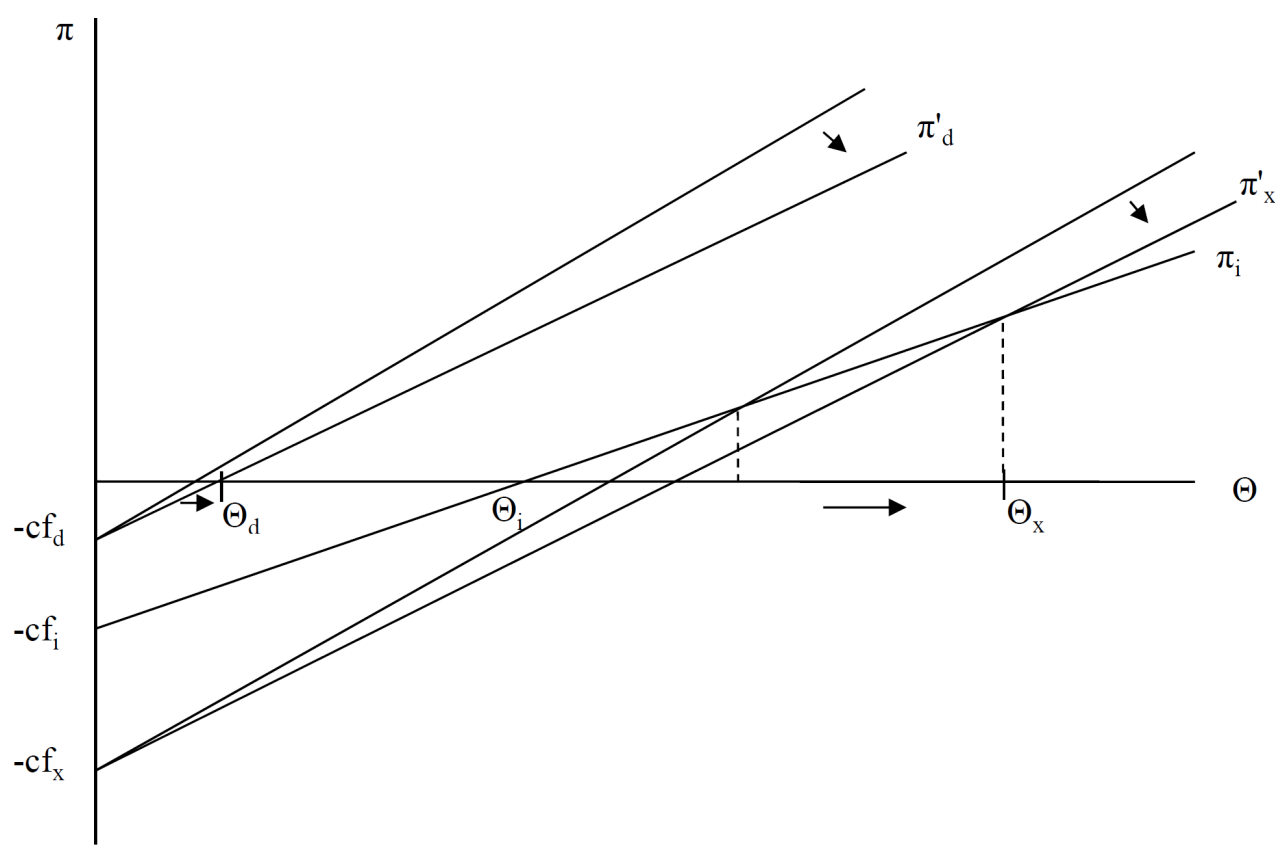

This generates a number of important, testable predictions. First, in Figure 3 it is evident that corruption increases the productivity cutoff $\left(\Theta_{d}\right)$ above which firms earn positive profits. In other imposes an additional fixed cost on firms.

${ }^{12}$ This rather strong assumption is made for illustrative purposes. However, the predictions of the model hold as long as corruption (modeled either as a variable or a fixed cost) has a relatively larger effect on domestic and direct export profits. 
words, corruption makes it more costly to operate and as a result fewer firms find it profitable to enter this market and sell domestically. ${ }^{13}$ This leads to the following proposition:

Proposition 2 Corruption decreases the likelihood that a firm will only sell domestically.

One difficulty in testing this prediction is that economists seldom have information on the firms that are no longer operating within a market. However, it is important to note that $\Theta_{i}$ remains unchanged, since indirect exporting is relatively immune to corruption. Therefore, the total number of exporters, including both indirect and direct, should not change significantly. Thus, the range of productivities over which a firm will choose to sell only domestically $\left(\Theta_{d}\right.$ to $\left.\Theta_{i}\right)$ decreases due to corruption but the range of productivities over which a firm exports (greater than $\Theta_{i}$ ) does not change.

There are a variety of ways to test this proposition. First, at the aggregate level, the ratio of the number of exporters to the number of purely domestic firms will be higher in corrupt markets. This is due to the fact that corruption reduces the number of domestic firms while leaving the number of exporters relatively unaffected. Second, the average productivity of domestic firms will be higher in markets with high corruption. This is not because corruption increases productivity but rather because only the more productive firms find it profitable to operate in corrupt markets. Third, at the individual firm-level, the probability that a firm chooses to be an exporter is higher in a corrupt economy. In other words, relative to exporting, the likelihood that a firm only sells domestically decreases due to corruption.

The model also generates testable predictions about how corruption affects the trade-off between indirect and direct exporting. Although the same set of firms find it profitable to export, since $\Theta_{i}$ remains relatively fixed, the type of exporting that firms find most profitable changes in response to corruption. Specifically, since $\Theta_{x}$ increases in response to corruption, there will be a substitution away from direct exporting and towards indirect exporting. This generates the following prediction:

Proposition 3 Conditional on exporting, corruption increases the likelihood that a firm indirectly exports and decreases the likelihood that a firm directly exports.

\footnotetext{
${ }^{13}$ In addition to this main effect, the reduction in the number of direct exporters can generate a general equilibrium effect which will decrease the domestic cutoff (Helpman 2006). However, this indirect effect will not be large enough to overturn the direct impact of corruption which increases $\Theta_{d}$.
} 
The intuition for this prediction can easily be seen in Figure 3. Firms find it more profitable to indirectly export if their productivity is between $\Theta_{i}$ and $\Theta_{x}$ and this range has increased due to corruption. However, firms choose to directly export if their productivity is above $\Theta_{x}$ and this range of productivities has decreased due to corruption.

Again there are a variety of ways to test this proposition. First, at the aggregate level, the ratio of the number of indirect exporters relative to the number of direct exporters will be higher in corrupt markets. Second, average productivity of both indirect and direct exporters will be higher in corrupt economies. Due to corruption, the least productive direct exporters now become the most productive indirect exporters, and thus the average productivity of both types of firms increase. Third, at the firm level, the probability that a firm chooses to access foreign markets through an intermediary increases due to corruption.

An additional prediction of the model is that the direct export cutoff should increase by more than the entrance cutoff. As Figure 3 shows, $\Theta_{x}$ increases by relatively more in response to corruption. This occurs because the $\Theta_{x}$ cutoff is defined by where $\pi_{x}$ intersects the upward sloping $\pi_{i}$ curve whereas the $\Theta_{d}$ cutoff is defined by where $\pi_{d}$ intersects the horizontal axis (i.e. becomes positive). Thus, an equivalent shift in the $\pi_{d}$ and $\pi_{x}$ leads to a larger change in the cutoff between indirect and direct exporting. Therefore, relative to the decline in the probability that a firm only sells domestically, corruption will lead to a larger decrease in the probability that a firm directly exports.

The model has generated a number of testable predictions based on some reasonable assumptions about how corruption affects the costs of production and thus the profits associated with accessing different markets. With that said, there are obviously other assumptions that would lead to a very different set of predictions. Thus, the validity of the theoretical framework is ultimately an empirical question. The remainder of the paper will examine to what extent the empirical results support the propositions of the model.

\section{Empirical Specification}

This section presents the empirical specification that is used to test the propositions generated by the model. First, a test of the self-selection of firms according to their productivity is discussed. 
Second, the impact of corruption on the firm's likelihood of selling domestically, exporting indirectly, or exporting directly will be examined both at the aggregate level and at the firm level. Finally, the instruments used to overcome potential endogeneity and measurement error concerns will be presented.

\subsection{Self-Selection of Firms}

Confirming the ordering of firms according to their productivity is an important first step before the impact of corruption can be studied. Proposition 1 is tested by estimating the following equation:

$$
\ln (\text { prod })_{j c s t}=\alpha_{1} i n d \_e x p \_d u m_{j c s t}+\alpha_{2} d i r \_e x p \_d u m_{j c s t}+\lambda_{c}+\lambda_{s}+\lambda_{t}+\varepsilon_{j c s t},
$$

where prod is the productivity of firm $j$ in country $c$, sector $s$, and year $t$. ind_exp_dum is a binary variable which equals one if the firm sells domestically and indirectly exports, while dir_exp_dum is a binary variable that equals one if the firms sells domestically and directly exports. Finally, $\lambda_{c}$ are country fixed effects, $\lambda_{s}$ are sector fixed effects, and $\lambda_{t}$ are year fixed effects. Proposition 1 of the model predicts that domestic firms are the least productive, indirect exporters are more productive, and direct export are the most productive. Since domestic firms are the excluded group in Equation (6), this implies that $0<\alpha_{1}<\alpha_{2}$.

\subsection{Impact of Corruption at the Aggregate Level}

Next, the impact of average corruption on aggregate country-sector-year level measures is examined. Specifically, the number of domestic, indirect exporters, and direct exporters is calculated for each country, sector, and year market. Then the impact of average corruption on the following ratios is estimated:

$$
\text { exp } / \text { dom }_{c s t}=\alpha_{1} \text { corrupt_mean }{ }_{c s t}+\lambda_{c}+\lambda_{s}+\lambda_{t}+\varepsilon_{c s t}
$$




$$
\text { ind_exp/dir_exp } \operatorname{esst}_{1}=\beta_{1} \text { corrupt_mean }{ }_{c s t}+\lambda_{c}+\lambda_{s}+\lambda_{t}+\varepsilon_{c s t},
$$

where exp/dom is the ratio of the number of exporting firms to the number of domestic firms, ind_exp/dir_exp is the ratio of the number of indirect exporters to the number of direct exporters, and corrupt_mean is the average corruption level at the country-sector-year level. The full set of fixed effects are included in Equations (7) and (8) as well.

Proposition 2 of the model predicts that $\alpha_{1}>0$ in Equation (7). Markets with higher levels of corruption should have a higher $\Theta_{d}$ cutoff while the $\Theta_{i}$ cutoff will be relatively unaffected. As a result, corruption leads to fewer firms finding it profitable to enter the market and sell domestically, and therefore the ratio of exporters to domestic firms will increase. Equation (8) tests Proposition 3 of the model, which states that corruption will also increase the $\Theta_{x}$ cutoff. As a results, the number of indirect exporters relative to the number direct exporters will increase in markets characterized by high levels of corruption. Some exporters will find it more profitable to indirectly export through an intermediate rather than to directly export themselves. As a result, the model predicts that $\beta_{1}>0$.

The model also generates predictions about how corruption will affect the average productivity levels of domestic firms, indirect exporting firms, and direct exporting firms at the country-sectoryear level. Thus, the following equation will be estimated for each type of firm:

$$
\ln (\text { productivity_mean })_{c s t}=\delta_{1} \text { corrupt_mean }{ }_{c s t}+\lambda_{c}+\lambda_{s}+\lambda_{t}+\varepsilon_{c s t},
$$

where productivity_mean is the average productivity of domestic firms, indirect exporting firms, and direct exporting firms depending on the specification.

According to the model, the $\Theta_{d}$ cutoff increases due to corruption. Thus, the average productivity of domestic firms operating in a market will increase with corruption. This is because the least productive domestic firms are not profitable in the corrupt market and thus exit. The model also predicts that the $\Theta_{x}$ cutoff will increase. Thus, the average productivity of indirect exporters 
and direct exporters should both increase as the least productive direct exporters now become the most productive indirect exporters. So corruption will increase the average productivity of each type of firm, and thus $\delta_{1}>0$ in all three specifications.

\subsection{Impact of Corruption at the Firm Level}

The impact of corruption on the selection of firms into different production modes is now examined at the firm level. This empirical specification fully exploits the richness of the Enterprise Survey data. Specifically, the predictions of the model are tested by estimating the following equations:

$$
e x p_{-} d u m_{j c s t}=\alpha_{1} \text { corrupt }_{j c s t}+\lambda^{\prime} X_{j c s t}+\lambda_{c}+\lambda_{s}+\lambda_{t}+\varepsilon_{j c s t},
$$

$$
i n d \_e x p \_d u m_{j c s t}=\beta_{1} \text { corrupt }_{j c s t}+\lambda^{\prime} X_{j c s t}+\lambda_{c}+\lambda_{s}+\lambda_{t}+\varepsilon_{j c s t},
$$

where $e x p \_d u m$ is a binary variable that equals one if the firm exports and zero if the firm only sells domestically. ind_exp_dum is the indirect exporting dummy variable discussed previously. Given that the unit of observation is now at the firm level, it is possible to include a vector of firm-level control variables $(X)$, such as productivity, age, size, and the share of foreign ownership. Country fixed effects $\left(\lambda_{c}\right)$, sector fixed effects $\left(\lambda_{s}\right)$, and year fixed effects $\left(\lambda_{t}\right)$ are included as well. ${ }^{14}$ Equations (10) and (11) are estimated using a probit regression since the dependent variables are binary. ${ }^{15}$ Finally, all subsequent regressions have robust standard errors which are clustered at the country-industry level to account for potential correlation in the error terms.

According to Proposition 2, corruption will increase the $\Theta_{d}$ cutoff but leave the $\Theta_{i}$ relatively unchanged. As a result, the range of productivities over which a firm chooses to sell only domestically shrinks but the range of productivities over which a firm chooses to export remains the same.

\footnotetext{
${ }^{14}$ Section 6.2 shows that the results are robust to using interacted pair FE (i.e. country*year, sector*year, and country*sector) as well as country*sector*year FE. However, given the nature of the instruments, it is not possible to use these alternate fixed effect strategies in the IV probit analysis.

${ }^{15}$ Estimating Equations (10) and (11) using a nested logit specification is not possible because there are no alternative-specific control variables in this analysis. Furthermore, the current empirical specificaiton is appealing because it offers the flexibility to control the counterfactual group and the ability to pursue an IV analysis.
} 
Thus, $\alpha_{1}>0$ in Equation (10) because as corruption increases, the probability that a firm is an exporter increases.

To test Proposition 3, it is important to condition on exporting in order to more carefully focus on the impact of corruption on the $\Theta_{x}$ cutoff. Including purely domestic firms in this analysis would attenuate the estimated impact of corruption on $\Theta_{x}$ since $\Theta_{d}$ is also increasing. Thus, restricting the sample to just firms that export, focuses the empirical analysis more carefully on the impact of corruption on the tradeoff between indirectly exporting and directly exporting. Thus, in Equation (11) the sample is restricted to only firms that export and the model predicts $\beta_{1}>0$. In other words, corruption increases the probability that a firm indirectly exports and decreases the probability that a firm directly exports.

\subsection{Instrument}

The goal of this empirical specification is to identify the causal impact of corruption on firm selection into different modes of operation. Since corruption is usually ubiquitous to a business environment, while the entrance into different modes of operation is a firm specific decision, it is likely that Equations (10) and (11) are identifying this causal effect. Furthermore, the inclusion of firm level controls, country fixed effects, industry fixed effects, and year fixed effects further reduce fears of endogeneity.

However, there may still be lingering concerns about the empirical specification. For instance, the model predicts that the likelihood that a firm indirectly exports should increase relative to the other modes of operation since intermediaries are better equipped to deal with corrupt government officials. However, it may also be possible that indirect exporters could report more corruption since they have to rely on a middleman to help facilitate sales abroad. This reverse causality would be problematic for this analysis since it would introduce a spurious positive bias into the $\alpha_{1}$ and $\beta_{1}$ coefficients in Equations (10) and (11). ${ }^{16}$ In addition, measurement error is likely a problem in this type of analysis since corruption is an inherently secretive affair and is thus likely to be a noisy variable (Fisman and Svensson 2007). However, measurement error would, if anything, attenuate

\footnotetext{
${ }^{16}$ An alternate story is that perhaps corrupt officials are more likely to extract bribes from larger, wealthier, and more productive firms. However, this source of endogeneity would work against the empirical findings. It would imply that corruption and direct exporting should be positively correlated, since direct exporters are larger and more productive. Thus, this story would introduce a spurious positive bias that should if anything attenuate the $\beta_{1}$ coefficient.
} 
the estimated $\alpha_{1}$ and $\beta_{1}$ coefficients.

To overcome potential endogeneity and measurement error concerns, this analysis uses an IV probit estimation strategy to more carefully identify the causal impact of corruption on production mode decisions. Specifically, this analysis utilizes two very different instruments. First, following Fisman and Svensson (2007) the average corruption level of other firms within the same countryindustry-year is used as an instrument. Specifically, for each country-industry-year the average level of corruption of firms not including firm $j$ itself is calculated. This average corruption level is used as the instrument for firm $j$ 's corruption level. This strategy minimizes endogeneity concerns and measurement error issues by identifying variation in firm level corruption that is due to factors that are common to other firms within that specific market. Thus, this instrument avoids variation in reported corruption that is driven by idiosyncratic characteristics of firm $j$ which could be correlated with sales.

The second instrument uses firm-level information on whether gifts or informal payments were expected by government officials in a variety of contexts. Specifically, seven separate binary variables indicate whether a bribe was requested in order to obtain an electrical connection, a water connection, a telephone connection, a construction permit, an import license, an operating license, or whether a bribe was requested by a tax inspector. ${ }^{17}$ Using these variables, a categorical variable called Total Bribes is constructed that indicates how many bribes were requested of the firm. This instrument more carefully identifies the source of corruption, by focusing on bribes requested by government officials. This is appealing because it alleviates the most obvious source of reverse causality, namely that indirect exporters may report more corruption simply because they are dealing with intermediaries. This IV eliminates this problematic source of variation in corruption and instead utilizes the more plausibly exogenous variation stemming from corrupt government officials.

Utilizing these two instruments, Equations (10) and (11) will be re-estimated using an IV probit specification. The subsequent results indicate that both of these instruments are strong and satisfy the exclusion restriction. In other words, both instruments are good at predicting actual corruption and they only affect the dependent variables through their impact on corruption.

\footnotetext{
${ }^{17}$ Each of these variables combine information from the Enterprise Survey on whether the firm applied for the relevent permit and if so whether a bribe was requested. Unlike other measures in the Enterprise Survey (pursued in Appendix 8.6), these variables have very good coverage.
} 


\section{Data}

This paper uses the Enterprise Survey data set produced by the World Bank to test the predictions of the model. The Enterprise Survey gathers information from a stratified random sample of firms spanning a wide variety of countries, sectors, and years. The data is collected by conducting in-depth, face-to-face interviews of business owners and managers in developing countries throughout the world. Importantly, the data has firm-level information on domestic sales, exports, and corruption which is especially useful for this analysis. While the subjectivity of responses in any survey like this is a potential caveat, survey based datasets provide the only consistent measure of corruption across countries and over time (Olken and Pande 2012).

Consistent with the types of firms considered in the model, the empirical analysis focuses on private manufacturing firms that have a positive level of sales. To ensure sufficient firm-level variation within each market, the sample is restricted to country-sector-years that have at least ten observations and to those countries with at least one domestic, indirect exporting, and direct exporting firm. Unfortunately, the Enterprise Survey is limited to at most two years of data per country and firms are not linked across years (although this is a priority for the Enterprise Survey moving forward). Despite these drawbacks, the data used in this analysis includes 23,317 firms from 11 different manufacturing industries, 80 different less-developed countries, and six different years (2005-2010). This provides the scope and scale necessary to examine the implications of corruption on export decisions.

\subsection{Sales}

The Enterprise Survey asks firms what their total annual sales were in the last fiscal year. They also ask what percentage of sales were "national sales," what percentage were "indirect exports (sold domestically to third party that exports product)," and what percentage were "direct exports." Thus, this data set identifies firms that indirectly export through intermediaries, which provides a unique opportunity to test the predictions of the model.

Using this information, three binary, mutually exclusive definitions of firm type are constructed which match the types of the firms considered in the model. Specifically, the domestic dummy variable equals one if the firm only sells to the domestic market, and zero otherwise. The indirect 
export dummy equals one if the firm sells domestically and exports indirectly, and zero otherwise. Finally, the direct export dummy equals one if the firm sells domestically and exports directly, and zero otherwise.

\subsection{Corruption}

The Enterprise Survey data also has information about the level of corruption that firm's face. Specifically, the World Bank asks "To what degree is corruption an obstacle to the current operations of this establishment?" The responses are relatively evenly distributed across the options: "No Obstacle," "Minor Obstacle," "Moderate Obstacle," "Major Obstacle," and "Very Severe Obstacle." These responses are then used to construct a categorical variable taking on values of zero through four with zero representing "No Corruption" and four representing "Very Severe Obstacle." 18

There are a number of appealing aspects of this measure of corruption. First, it is one of the only consistent measures of corruption across countries and over time. Second, nearly all firms respond to this question and thus this variable has remarkably good coverage in the Enterprise Survey data set. Third, the focus on less developed countries is appealing since corruption is likely to be a more severe impediment to operations in these countries. Finally, to the best of my knowledge, this is the only measure of corruption at the firm-level which provides a number of empirical options and benefits relative to the more aggregate country level measures.

\subsection{Controls}

The estimation strategy includes fixed effects which control for unobserved differences that are constant within countries, sectors, and years. In addition, the empirical analysis accounts for firm specific characteristics. Specifically, it controls for productivity, which is defined as sales per employee following Ahn et al. (2011) and Bernard et al. (2013). In addition, the age of the firm, the size of the firm (small, medium, or large based on employment), and the share of foreign ownership are also included as controls. ${ }^{19}$

\footnotetext{
${ }^{18}$ See Section 6.2 for an alternate treatment of the corruption variable in which each response is treated as its own separate binary variable. In addition, the results that follow are robust to using other measures of corruption provided by the Enterprise Survey.

${ }^{19}$ Numerous other firm level controls were tried (including alternate productivity measures, some of which are shown in section 6.2) but these four were identified as the most important and empirically significant.
} 


\subsection{Descriptive Statistics}

Table 1 reports the summary statistics for all firms, domestic firms, indirect exporting firms, and direct exporting firms. Consistent with previous findings (Bernard et al. 2007), the majority of firms serve the domestic market only. However, Table 1 indicates that 6,111 firms, or $26 \%$ of the firms in the sample, export either indirectly or directly. Also consistent with existing research, we see that exporting firms tend to be more productive, larger, older and they have more sales and higher profits.

Figure 4 examines whether corruption is correlated with an increased prevalence of indirect exporting. Figure 4 is similar to Figure 1 except that now the unit of observation is at the countrysector-year level. Specifically, the measure of corruption is averaged up to the country-sector-year level and plotted against the share of indirect exporters. In the top panel, there is a positive relationship between average corruption and the share of indirect exporters. The bottom panel is an analogous scatter plot after accounting for country fixed effects, sector fixed effects, and year fixed effects. After controlling for inherent differences across markets, there is an even stronger positive relationship between corruption and indirect exporting. Certainly these basic scatter plots should be interpreted with caution. However, it is interesting and encouraging that these relationships emerge in such a raw cut of the data. Overall these scatter plots provide preliminary evidence that in corrupt markets, indirect exporters are more prevalent. The analysis that follows examines whether these relationships survive a more rigorous empirical approach. 
Figure 4

Share of Indirect Exporters and Average Corruption

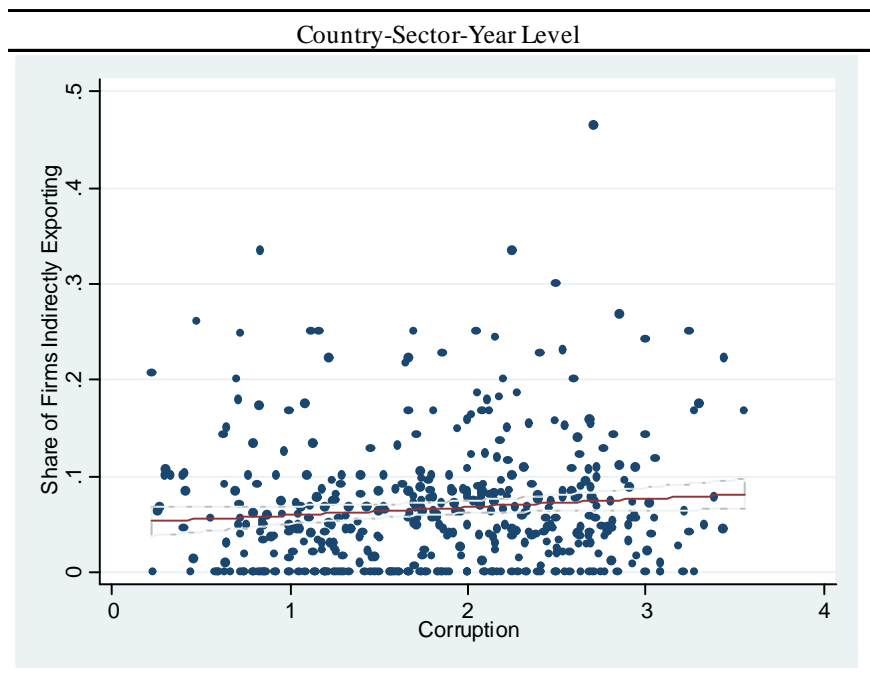

Country-Sector-Year Level (controlling for country , sector , and year FE)

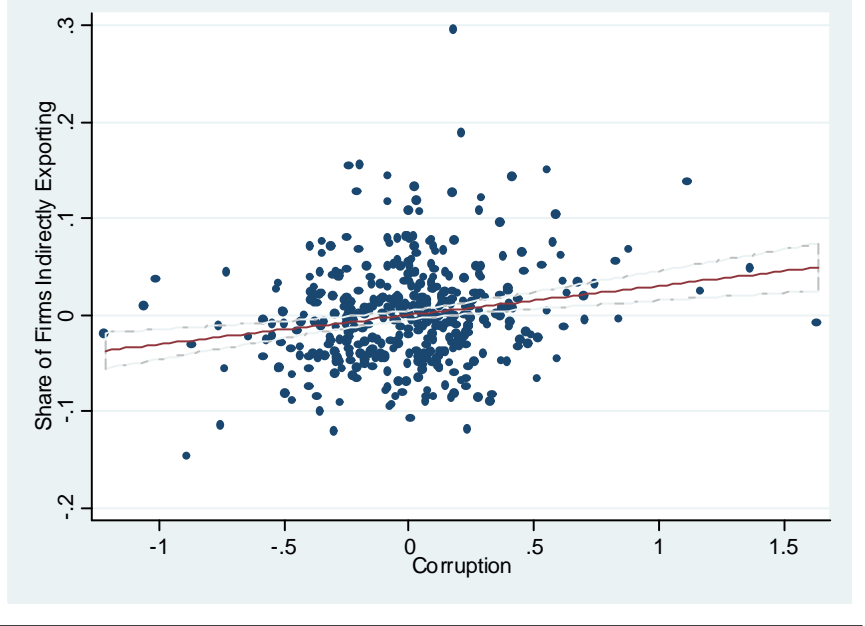

The top panel plots the share of indirect exporters against average corruption at the country-sector-year level. The bottom panel is analogous except it controls for country FE, sector FE, and year FE.

\section{Results}

This section examines whether the empirical results support the key propositions of the model. First, this analysis examines whether firms select into different production modes according to their productivity. Second, the impact of corruption on aggregate-level variables is studied. Third, the impact of corruption at the firm-level is examined. Finally, an firm-level IV analysis deals with endogeneity and measurement error issues. 


\subsection{Self Selection of Firms}

First, I examine whether low productivity firms choose to serve the domestic market only, more productive firms choose to indirectly export, and the most productive firms choose to directly export. Specifically, the results from estimating Equation (6) are reported in Table 2. All results include country fixed effects, sector fixed effects, year fixed effects, and have clustered standard errors in brackets.

The first column of Table 2 indicates that indirect exporters are relatively more productive than domestic firms, which is the excluded group. In addition, the coefficient on the direct export dummy variable indicates that direct exporting firms are the most productive. Both coefficients are significant at the one percent level. Also, since exporters are more productive and are selling to both the domestic and foreign markets, we see in column 2 that they earn higher profits. As the model predicts, indirect exporters earn higher profits than domestic firms while direct exporters earn the highest profits. ${ }^{20}$ Again both coefficients are significant at the one percent level.

Overall, there is strong support for Proposition 1 that the least productive firms sell domestically only, the middle productivity firms indirectly export, and the most productive firms directly export. The fact that this first prediction of the model is confirmed provides support for the model's assumptions regarding the fixed and variable costs of production. In addition, these finding are consistent with existing evidence that exporters are more productive than domestic firms (Bernard et al. 2007) and that direct exporters are more productive than indirect exporters (Bernard et al. 2013).

\subsection{Aggregate Analysis}

With the ordering of firms according to productivity confirmed, it is now possible to turn to the implications of corruption. This aggregate level analysis begins by estimating Equations (7) and (8) with the results reported in Table 3. These aggregate results include country fixed effects, sector fixed effects, year fixed effects, and have robust standard errors in brackets.

Column 1 of Table 3 indicates that a one unit increase in average corruption increases the

\footnotetext{
${ }^{20}$ Firm profits are calculated as the difference between total sales and the sum of various individual costs facing the firm. It is not possible to separately calculated costs associated with domestic sales, indirect exports, or direct exports and thus this profit measure is not used in the subsequent analysis. Despite the imprecision with which profits are calculated, these results are encouraging.
} 
ratio of exporters to domestic firms by 20 percentage points. This supports Proposition 2 of the model and indicates that corruption decreases the number of purely domestic firms relative to the number of exporters. Low productivity domestic firms are unable to survive in markets with severe corruption and as a result the share of exporters is higher.

The results in column 2 shows that a one unit increase in average corruption increases the ratio of indirect exporters to direct exporters by 30 percentage points. This supports Proposition 3 of the model, which predicts that the share of indirect exporters to direct exporters is increasing with corruption. In markets with severe corruption, many firms find it more profitable to indirectly export through an intermediary.

Next, the impact of corruption on the average productivity of the three different firm types is examined. Specifically, Table 4 reports the results from estimating Equation (9). Column 1 shows that corruption increases the average productivity of domestic firms which is consistent with the second proposition of the model. Due to corruption the least productive firms exit the market, and as a result the average productivity of the remaining firms is higher.

The results in columns 2 and 3 show that corruption increases the average productivity of indirect and direct exporters as well. This is consistent with the third proposition of the model. Corruption causes the $\Theta_{x}$ cutoff to increase and as a result the least productive direct exporters now become the most productive indirect exporters. Thus, the average productivity of both indirect and direct exporters increases.

Overall, the aggregate results in Tables 3 and 4 provide strong support for the propositions of the model. However, to more carefully test these predictions and to fully exploit the appealing dimensions of the data, a firm-level analysis is pursued in the next section.

\subsection{Firm-Level Analysis}

Table 5 reports the probit results from estimating Equations (10) and (11). The dependent variable in columns 1-3 is the dummy variable indicating whether a firm exports or sells domestically, while the dependent variable in columns $4-6$ is a dummy variable indicating whether a firm indirectly exports or directly exporters. All firm-level regressions report the probit marginal effects with clustered standard errors in brackets.

Focusing first on the decision of whether to export, column 1 reports the most basic empirical 
specification, column 2 adds fixed effects, and column 3 adds both the fixed effects and the firm-level controls. In all three specifications corruption increases the likelihood that a firm is an exporter relative to being purely domestic. This finding supports the second proposition of the model that fewer firms find it profitable to only sell domestically since the $\Theta_{d}$ cutoff has increased. Consistent with the results from Table 2, the coefficients on the control variables in column 3 indicate that, relative to domestic firms, exporters are more productive, older, larger, and have a higher share of foreign ownership.

Columns 4-6 then focus on how firms choose to access the foreign market conditional on the decision to export. Again, column 4 includes no controls or fixed effects, column 5 adds fixed effects, and column 6 adds both fixed effects and controls. In all three specifications, the results indicate that corruption increases the likelihood that a firm will indirectly export through an intermediary. This supports the third proposition of the model which states that corruption will increases the likelihood that a firm indirectly exports and decreases the likelihood that a firm directly exports. Finally, consistent with Table 2, column 6 indicates that indirect exporters are less productive, younger, smaller, and have less foreign ownership relative to direct exporters.

In summary, the firm-level results in Table 5 provides compelling support for the predictions of the model. Corruption decreases the probability that a firm sells domestically only, increases the probability that a firm indirectly exports, and decreases the probability that a firm directly exports. Furthermore, the magnitude of the corruption coefficient is larger in column 6 than in column 3 which is consistent with the prediction of the model that the $\Theta_{x}$ cutoff will increase by more than the $\Theta_{d}$ cutoff.

\subsection{Firm-Level IV Analysis}

This section identifies the causal impact of corruption on the selection of firms into domestic and export markets. Specifically, IV probit results from estimating equations (10) and (11) are reported in Table 6. All regressions include the full set of fixed effects, all the firm-level controls, and they report marginal effects with clustered standard errors in brackets.

The first stage IV probit results are reported in the bottom half of Table 6 . In columns 1 and 3, the Mean Corruption and Total Bribes instruments have a significant positive impact on firm-level corruption. Specifically, firms report higher corruption levels if other firms within their particular 
country, sector, and year are exposed to corruption and if government officials are requesting bribes. Columns 2 and 4 pursue a slightly different approach by using the individual bribe components as instruments rather than the sum of these binary variables. The vast majority of these individual components have a positive and significant impact on firm level corruption. Reassuringly, all of the first stage F-stats in Table 6 are well above 10, which indicates these are strong instruments. In addition, the high Hansen $\mathrm{J}$ p-values indicates a failure to reject the null that the instruments are valid and uncorrelated with the error term. ${ }^{21}$ The results from this overidentification test alleviate concerns that the instruments are directly affecting the dependent variable and thus violating the exclusion restriction.

The second stage IV probit results are reported in the top panel of Table 6. The results in columns 1 and 2 show that corruption has a positive and significant impact on the likelihood that a firm exports. A one unit increase in corruption increases the probability that a firm is an exporter by about $6 \%$ or in other words decreases the probability that a firm is purely domestic by $6 \%$. This supports the predictions of the model that corruption reduces the likelihood that a firm sells only domestically. After accounting for endogeneity concerns and measurement error, the causal impact of corruption on the selection of firms into the export market remains positive and significant.

The second stage IV probit results in columns 3 and 4, indicate that a one unit increase in corruption increases the probability that a firm indirectly exports by about 6-7\%. This is consistent with the predictions of the model and shows that corruption increases the likelihood that a firm indirectly exports and reduces the likelihood that a firm directly exports. Using government bribes as an IV addresses the most obviously form of reverse causality, namely that indirect exporters report more corruption simply because they have to deal with middlemen. In addition, using mean corruption levels of other firms addresses measurement error concerns associated with firm-reported corruption. We see in Table 6 that after addressing endogeneity and measurement error using this IV probit approach, the results are still significant and of the expected sign. ${ }^{22}$

The magnitude of the IV probit results in Table 6 are larger than the analogous probit results in columns 3 and 6 of Table 5 . Although it is possible that endogeneity is attenuating these results, it

\footnotetext{
${ }^{21}$ The first stage F-stat and the Hansen $\mathrm{J}$ p-value are from a linear IV specification since neither are reported in a typical IV Probit specification.

${ }^{22}$ Appendix 8.5 shows that the results are robust to a variety of other IV approaches, including separately using the bribe components as IVs and using other measures provided by the Enterprise Survey as instruments.
} 
seems more likely that the corruption variable is suffering from measurement error which is biasing these probit results towards zero (Angrist and Krueger 2001). This explanation seems especially plausible given the difficulty in measuring an inherently noisy variable like corruption (Fisman and Svensson 2007).

The empirical analysis has become increasingly sophisticated. First, the impact of average corruption on aggregate country-sector-level measures was examined. Second, a firm-level analysis was pursued that used firm-level corruption and controlled for firm characteristics and fixed effects. Finally, an IV approach was pursued that more carefully identified the causal impact of corruption. Despite these various empirical strategies a surprisingly consistent story has emerged which supports the predictions of the model. Corruption decreases the probability that a firm sells domestically only, increases the probability that a firm indirectly exports, and decreases the probability that a firm directly exports.

\section{Extensions}

\subsection{Intensive Margin}

The analysis so far has focused on the impact of corruption on the likelihood that a firm selects into a particular mode of operation. This captures the extensive margin of adjustment, which is consistent with the predictions of the model. In addition, it is also possible that corruption has an impact on the firm's intensive margin. Thus, this section examines whether corruption affects the profits of existing firms.

Unfortunately, it is not possible, due to data constraints, to separately identify profits obtained from domestic and export sales, because in the Enterprise Survey data the firm's costs are not defined by the destination market. However, total profits including profits from both domestic and foreign markets can be calculated for each type of firm. According to the model, corruption reduces domestic profits for all firms and also reduces direct export profits. Therefore, profits for purely domestic firms will obviously decrease. Corruption will also have a negative impact on the total profits of indirect firms as well. Specifically, it will not reduce indirect profits but it will reduce the domestic profits of these firms. Finally, corruption will lead to a large reduction in the profits of direct exporters for two reasons. First, both their domestic and their export profits decline with 
corruption. In addition, for these larger firms the variable costs of corruption leads to a relatively large decline in profits (as seen in Figure 3).

The results of this intensive margin test are reported in Table 7. Specifically, the impact of corruption on domestic firm profits and on indirect firm profits is insignificant in columns 1 and 2 . However, in column 3 a one unit increase in corruption decreases profits for direct exporters by $4 \%$. As expected corruption has the most negative impact on the profits of direct exporters. Despite this significant result, overall the intensive margin results are relatively weak. This is consistent with a large body of research that shows that extensive margin adjustments are crucial in understanding international trade flows (see for instance Bernard et al. 2007).

\subsection{Sensitivity Analysis}

Table 8 examines whether the baseline findings are robust to a variety of alternate specifications. First, in columns 1 and 5 interacted pairwise fixed effects are included (i.e. country*year, sector*year, and country*sector) rather than including them individually as was done in the baseline specification. Columns 2 and 6 then go one step further by including instead country*sector*year fixed effects. The coefficients on corruption in the baseline specification as well as in these extensions are all very similar. ${ }^{23}$ Clearly, the results are robust to alternate fixed effect strategies.

Columns 3 and 7 use an alternate measure of productivity. Specifically, TFP is calculated as the residual term after regressing total sales on the replacement value of machinery, total compensation of workers, and intermediary goods following the method proposed by Saliola and Seker (2011). ${ }^{24}$ The drawback of using this TFP measure is that the number of observations decreases by about a third. However, the coefficients on the TFP measure are of the expected sign and significant. Furthermore, the coefficient on corruption remains virtually unchanged when this alternate measure of productivity is used.

In the baseline specification, the corruption variable is treated as a categorical variable. Instead in columns 4 and 8 of Table 8 the various corruption responses are coded as separate binary variables. For instance, Corrupt 0 equals one if the firm said that corruption was "no obstacle" and zero otherwise. This is repeated for all five possible responses to the corruption question. The

\footnotetext{
${ }^{23}$ This may in part be due to the fact that the time dimension in the Enterprise Survey data is minimal.

${ }^{24}$ The results are also robust to the use of a variety of other measures of productivity.
} 
results show that, relative to corruption being no obstacle (Corrupt 0 is the excluded group), those firms that responded that corruption was a major obstacle or a very severe obstacle (Corrupt 3 and Corrupt 4 respectively) are more likely to export (column 4) and are more likely to export indirectly (column 8). Not surprisingly, it is the more severe forms of corruption that significantly affect the self-selection of firms into different production modes.

\section{Conclusion}

This paper constructs a model that predicts how firms self-select into domestic, indirect export, and direct export modes of production based on their productivity. Then the impact of corruption on the selection of firms into these modes of operation is examined. Overall, the theoretical framework generates a number of specific and testable predictions.

The propositions of the model are tested using a unique and comprehensive data set on over 23,000 firms in 80 developing countries. The empirical analysis confirms the predictions of the model. First, relatively low productivity firms only sell domestically, more productive firms indirectly export, and the most productive firms directly export. Second, corruption reduces the probability that a firm will only sell domestically, since only the more productive domestic firms are able to overcome the additional costs associated with a corrupt business environment. Third, corruption increases the probability that a firm will indirectly export and decreases the probability that a firm will directly export. In corrupt environments, the least productive direct exporters now find it more profitable to indirectly export through an intermediary. These results are robust to a number of different specifications and approaches which provides strong support for the assumptions and predictions of the model.

Overall, this paper makes two important contributions. First, these results provide one of the first insights into how corruption affects the firm's decision to export. Given that corruption is a common impediment in developing countries and that access to foreign markets is often a source of growth and development, this is an important new finding. Second, these results highlight the importance of intermediaries in facilitating trade in corrupt developing countries. Specifically,

this paper provides compelling evidence that trade intermediaries insulate manufacturing firms from corrupt government officials. Thus, these intermediaries provide an important link to global 
markets especially in corrupt countries. 


\section{References}

Acemoglu, Daron, Simon Johnson, James A. Robinson. 2001. "The Colonial Origins of Comparative Development: An Empirical Investigation." American Economic Review, 91(5): 1369-1401.

Acemoglu, Daron, Simon Johnson, James A. Robinson. 2002. "Reversal of Fortune: Geography and Institutions in the Making of the Modern World Income Distribution." Quarterly Journal of Economics, 117(4): 1231-1294.

Ahn, JaeBin, Amit K. Khandelwal, and Shang-Jin Wei. 2011. "The Role of Intermediaries in Facilitating Trade." Journal of International Economics, 84: 73-84.

Angrist, Joshua D. and Alan B. Krueger. 2001. "Instrumental Variables and the Search for Identification: From Supply and Demand to Natural Experiments." The Journal of Economic Perspectives, 15(4): 69-85.

Antras, Pol and Arnaud Costinot. 2010. "Intermediation and Economic Integration." American Economic Review, 100(2):424-28.

Antras, Pol and Arnaud Costinot. 2011. "Intermediated Trade." The Quarterly Journal of Economics, 126(3): 1319-1374.

Bardhan, Pranab. 1997. "Corruption and Development: A Review of Issues." Journal of Economic Literature, 35(3): 1320-1346.

Basker, Emek and Pham Hoang Van. 2010. "Imports "R" Us: Retail Chains as Platforms for Developing-Country Imports." American Economic Review, 100(2): 414-18.

Bernard, Andrew B., J. Bradford Jensen, Steven J. Redding, Peter K. Schott. 2007. "Firms in International Trade." The Journal of Economic Perspectives, 21(3): 105-130.

Bernard, Andrew B., J. Bradford Jensen, Steven J. Redding, Peter K. Schott. 2010. "Wholesalers and Retailers in US Trade." American Economic Review, 100(2): 408-413.

Bernard, Andrew B., Marco Grazzi, and Chiara Tomasi. 2013. "Intermediaries in International Trade: Margins of Trade and Export Flows." mimeo. 
Blum, Bernardo S., Sebastian Claro, and Ignatius Horstmann. 2010. "Facts and Figures on Intermediated Trade." American Economic Review, 100(2): 419-23.

Djankov, Simeon, Rafael La Porta, Florencio Lopez-De-Silanes, and Andrei Shleifer. 2002. "The Regulation of Entry." The Quarterly Journal of Economics, 117(1): 1-37.

Dollar, David and Aart Kraay. 2004. "Trade, Growth, and Poverty." The Economic Journal, 114: F22-F49.

Feenstra, Robert C. and Gordon H. Hanson. 2004. "Intermediaries in Entrepot Trade: Hong Kong Re-Exports of Chinese Goods." Journal of Economics and Management Strategy, 13(1): 3-35.

Feyrer, James. 2009a. "Trade and Income - Exploiting Time Series in Geography." NBER Working Paper 14910.

Feyrer, James. 2009b. "Distance, Trade, and Income - The 1967 to 1975 Closing of the Suez Canal as a Natural Experiment." NBER Working Paper 15557.

Fisman, Raymond and Jakob Svensson. 2007. "Are Corruption and Taxation Really Harmful to Growth? Firm Level Evidence." Journal of Development Economics, 83(1): 63-75.

Frankel, Jeffrey A. and David Romer. 1999. "Does Trade Cause Growth?" The American Economic Review, 89(3): 379-399.

Fredriksson, Anders. 2014. "Bureaucracy Intermediaries, Corruption and Red Tape," Journal of Development Economics, 108: 256-273.

Helpman, Elhanan. 2006. "Trade, FDI, and the Organization of Firms." Journal of Economic Literature, 44(3): 589-630.

Levchenko, Andrei A. 2007. "Institutional Quality and International Trade." Review of Economic Studies, 74(3): 791-819.

Melitz, Marc J. 2003. "The Impact of Trade on Intra-Industry Reallocations and Aggregate Industry Productivity." Econometrica, 71(6): 1695-1725.

Mauro, Paolo. 1995. "Corruption and Growth." The Quarterly Journal of Economics, 110(3): 681712. 
Nunn, Nathan. 2007. "Relationship-Specificity, Incomplete Contracts, and the Pattern of Trade." Quarterly Journal of Economics, 122(2): 569-600.

Olken, Benjamin A. and Rohini Pande. 2012. "Corruption in Developing Countries." Annual Review of Economics, 4(1): 479-509.

Rauch, James E. and Joel Watson. 2004. "Network Intermediaries in International Trade." Journal of Economics and Management Strategy, 13(1): 69-93.

Saliola, Federica and Murat Seker. 2011. "Total Factor Productivity Across the Developing World," Enterprise Survey, Enterprise Note Series, 23: 1-8.

Shleifer, Andrei and Robert W. Vishny. 1993. "Corruption." The Quarterly Journal of Economics, 108(3): 599-617.

Sourdin, Patricia and Richard Pomfret. 2012. "Trade Facilitation: Defining, Measuring, Explaining and Reducing the Cost of International Trade." Edward Elgar Publishing. 
Table 1

Summary Statistics

\begin{tabular}{|c|c|c|c|c|c|c|c|c|}
\hline & \multicolumn{2}{|c|}{ All Firms } & \multicolumn{2}{|c|}{ Domestic Only } & \multicolumn{2}{|c|}{ Indirect Exporters } & \multicolumn{2}{|c|}{ Direct Exporters } \\
\hline & Mean & Std. Dev. & Mean & Std. Dev. & Mean & Std. Dev. & Mean & Std. Dev. \\
\hline Firms & \multicolumn{2}{|c|}{23,317} & \multicolumn{2}{|c|}{17,206} & \multicolumn{2}{|c|}{1,400} & \multicolumn{2}{|c|}{4,711} \\
\hline $\ln$ (Profits) & 16.1 & 3.4 & 15.6 & 3.3 & 16.6 & 3.5 & 17.4 & 3.6 \\
\hline $\ln ($ Sales ) & 17.1 & 3.3 & 16.7 & 3.1 & 17.6 & 3.4 & 18.5 & 3.4 \\
\hline Corruption & 1.9 & 1.5 & 1.8 & 1.5 & 2.1 & 1.5 & 1.9 & 1.5 \\
\hline In (Productivity) & 13.8 & 2.9 & 13.7 & 2.8 & 14.0 & 3.0 & 14.0 & 3.0 \\
\hline $\ln ($ Age $)$ & 2.8 & 0.8 & 2.7 & 0.8 & 2.8 & 0.8 & 3.1 & 0.8 \\
\hline Size & 1.8 & 0.8 & 1.6 & 0.7 & 1.9 & 0.7 & 2.4 & 0.7 \\
\hline $\ln$ (Foreign) & 0.4 & 1.3 & 0.3 & 1.1 & 0.5 & 1.4 & 1.0 & 1.8 \\
\hline
\end{tabular}

Source: Enterprise Survey 
Table 2

Productivity and Profits of Direct and Indirect Exporters (OLS)

\begin{tabular}{lcc}
\hline & $\ln$ (Productivity) & $\ln$ (Profits) \\
\hline & $(1)$ & $(2)$ \\
\hline \multirow{2}{*}{ Indirect Export Dummy } & $0.266^{* * *}$ & $0.931^{* * *}$ \\
& {$[0.046]$} & {$[0.090]$} \\
Direct Export Dummy & $0.726^{* * *}$ & $2.185^{* * *}$ \\
& {$[0.038]$} & {$[0.079]$} \\
Country FE & Yes & Yes \\
Sector FE & Yes & Yes \\
Year FE & Yes & Yes \\
& & \\
Observations & 23,317 & 21,300 \\
R-squared & 0.808 & 0.614 \\
\hline
\end{tabular}

Robust standard errors clustered at the country-sector level in brackets. *** $\mathrm{p}<0.01$, ** $\mathrm{p}<0.05,{ }^{*} \mathrm{p}<0.1$. Domestic firms are the excluded group. 
Table 3

Impact of Average Corruption on the Ratio of Firm Types (OLS)

\begin{tabular}{lccc}
\hline & Exporters/Domestic & Indirect Exporters / Direct Exporters \\
\hline & $(1)$ & $(2)$ \\
\hline & & \\
Corruption (Mean) & $0.198^{* *}$ & $0.295^{* * *}$ \\
& {$[0.100]$} & {$[0.110]$} \\
Country FE & Yes & Yes \\
Sector FE & Yes & Yes \\
Year FE & Yes & Yes \\
& & \\
Observations & 430 & 391 \\
R-squared & 0.672 & 0.452 \\
\hline
\end{tabular}

Robust standard errors in brackets. $* * * \mathrm{p}<0.01, * * \mathrm{p}<0.05, * \mathrm{p}<0.1$. The dependent variable in Column (1) is the ratio of the number of exporting firms (either indirect or direct) to the number of domestic firms at the country-sector-year level. The dependent variable in Column (2) is the ratio of the number of indrect exporters to the number of direct exporters at the country-sector-year level. The independent variable is average firm corruption at the country-sector-year level. 
Table 4

Impact of Average Corruption on Average Productivity (OLS)

\begin{tabular}{lcccc}
\hline & Domestic Firms & Indirect Export Firms & Direct Export Firms \\
\hline & $(1)$ & $(2)$ & $(3)$ \\
Corruption (Mean) & & & $0.457^{* *}$ \\
& $0.891 * * *$ & $0.421^{*}$ & {$[0.224]$} \\
Country FE & {$[0.210]$} & {$[0.231]$} & Yes \\
Sector FE & Yes & Yes & Yes \\
Year FE & Yes & Yes & Yes \\
& Yes & Yes & 391 \\
Observations & & & 0.913 \\
R-squared & 430 & 337 & 0.896 & \\
\hline
\end{tabular}

Robust standards errors in brackets. *** $\mathrm{p}<0.01$, ** $\mathrm{p}<0.05, * \mathrm{p}<0.1$. The dependent variables are the $\ln$ of the average productivity of different types of firms at the country-sector-year level. The independent variable is average firm corruption at the country-sector-year level. 
Table 5

Impact of Corruption on Firm Selection into Export Markets (Probit)

\begin{tabular}{|c|c|c|c|c|c|c|}
\hline & \multicolumn{3}{|c|}{ Export Dummy } & \multicolumn{3}{|c|}{ Indirect Export Dummy (conditional on exporting) } \\
\hline & $(1)$ & $(2)$ & (3) & $(4)$ & $(5)$ & (6) \\
\hline Corruption & $\begin{array}{c}0.011 * * * \\
{[0.004]}\end{array}$ & $\begin{array}{c}0.006^{* *} \\
{[0.003]}\end{array}$ & $\begin{array}{c}0.006^{* *} \\
{[0.002]}\end{array}$ & $\begin{array}{c}0.013 * * * \\
{[0.005]}\end{array}$ & $\begin{array}{c}0.016 * * * \\
{[0.004]}\end{array}$ & $\begin{array}{c}0.013 * * * \\
{[0.004]}\end{array}$ \\
\hline $\ln$ (Productivity) & & & $\begin{array}{c}0.037 * * * \\
{[0.003]}\end{array}$ & & & $\begin{array}{c}-0.040 * * * \\
{[0.005]}\end{array}$ \\
\hline $\ln ($ Age $)$ & & & $\begin{array}{c}0.031 * * * \\
{[0.005]}\end{array}$ & & & $\begin{array}{c}-0.015^{*} \\
{[0.009]}\end{array}$ \\
\hline Size & & & $\begin{array}{c}0.179 * * * \\
{[0.007]}\end{array}$ & & & $\begin{array}{c}-0.135 * * * \\
{[0.009]}\end{array}$ \\
\hline $\ln ($ Foreign) & & & $\begin{array}{c}0.035 * * * \\
{[0.003]}\end{array}$ & & & $\begin{array}{c}-0.013 * * * \\
{[0.004]}\end{array}$ \\
\hline Country FE & No & Yes & Yes & No & Yes & Yes \\
\hline Sector FE & No & Yes & Yes & No & Yes & Yes \\
\hline Year FE & No & Yes & Yes & No & Yes & Yes \\
\hline Observations & 23,317 & 23,317 & 23,317 & 6,111 & 6,111 & 6,111 \\
\hline
\end{tabular}

Reported values are the estimated marginal effects with robust standard errors clustered at the country-sector level in brackets. $* * *$ $\mathrm{p}<0.01, * * \mathrm{p}<0.05, * \mathrm{p}<0.1$. The dependent variable in Columnns $1-3$ is a binary variable that indicates whether a firm exports. The dependent variable in Columnns 4-6 is a binary variable that indicates whether a firm indirectly exports, conditional on them exporting. 
Table 6

Impact of Corruption on Firm Selection into Export Markets (IV Probit)

\begin{tabular}{|c|c|c|c|c|}
\hline & \multicolumn{2}{|c|}{ Export Dummy } & \multicolumn{2}{|c|}{ Indirect Export Dummy (conditional on } \\
\hline & $(1)$ & $(2)$ & (3) & (4) \\
\hline \multirow[t]{2}{*}{ Corruption } & $0.060 * * *$ & $0.057 * * *$ & $0.068 * * *$ & $0.056^{* *}$ \\
\hline & {$[0.014]$} & {$[0.014]$} & {$[0.024]$} & {$[0.025]$} \\
\hline \multirow[t]{2}{*}{ ln (Productivity) } & $0.035 * * *$ & $0.038 * * *$ & $-0.039 * * *$ & $-0.041 * * *$ \\
\hline & [0.004] & {$[0.004]$} & {$[0.005]$} & {$[0.005]$} \\
\hline \multirow[t]{2}{*}{$\ln ($ Age $)$} & $0.029 * * *$ & $0.027 * * *$ & $-0.017 *$ & $-0.021 * *$ \\
\hline & {$[0.005]$} & {$[0.005]$} & {$[0.009]$} & [0.009] \\
\hline \multirow[t]{2}{*}{ Size } & $0.178 * * *$ & $0.177 * * *$ & $-0.128 * * *$ & $-0.131 * * *$ \\
\hline & {$[0.007]$} & {$[0.007]$} & [0.009] & [0.009] \\
\hline \multirow[t]{2}{*}{$\ln ($ Foreign) } & $0.035 * * *$ & $0.033 * * *$ & $-0.012 * * *$ & $-0.011 * * *$ \\
\hline & {$[0.003]$} & {$[0.003]$} & [0.004] & [0.004] \\
\hline Country FE & Yes & Yes & Yes & Yes \\
\hline Sector FE & Yes & Yes & Yes & Yes \\
\hline Year FE & Yes & Yes & Yes & Yes \\
\hline Observations & 23,316 & 21,326 & 6,111 & 5,542 \\
\hline \multicolumn{5}{|l|}{ First Stage IV Probit Results: } \\
\hline \multirow[t]{2}{*}{ Mean Corruption } & $0.489 * * *$ & $0.499 * * *$ & $0.277 * *$ & $0.303^{* * *} *$ \\
\hline & [0.084] & {$[0.085]$} & {$[0.115]$} & {$[0.115]$} \\
\hline \multirow[t]{2}{*}{ Total Bribes } & $0.349 * * *$ & & $0.381 * * *$ & \\
\hline & [0.018] & & {$[0.031]$} & \\
\hline \multirow[t]{2}{*}{ Electrical Bribes } & & $0.280 * * *$ & & $0.588 * * *$ \\
\hline & & {$[0.075]$} & & {$[0.124]$} \\
\hline \multirow[t]{2}{*}{ Water Bribes } & & $0.221 * *$ & & -0.140 \\
\hline & & {$[0.101]$} & & {$[0.235]$} \\
\hline \multirow[t]{2}{*}{ Telephone Bribes } & & $0.143^{*}$ & & $0.294 *$ \\
\hline & & {$[0.078]$} & & {$[0.154]$} \\
\hline \multirow[t]{2}{*}{ Construction Bribes } & & $0.337 * * *$ & & $0.398 * * *$ \\
\hline & & {$[0.063]$} & & {$[0.094]$} \\
\hline \multirow[t]{2}{*}{ Tax Official Bribes } & & $0.458 * * *$ & & $0.550 * * *$ \\
\hline & & {$[0.043]$} & & {$[0.063]$} \\
\hline \multirow[t]{2}{*}{ Import License Bribes } & & $0.367 * * *$ & & $0.269 * *$ \\
\hline & & {$[0.078]$} & & {$[0.133]$} \\
\hline \multirow[t]{2}{*}{ Operating License Bribes } & & $0.368 * * *$ & & $0.284 * * *$ \\
\hline & & {$[0.051]$} & & {$[0.100]$} \\
\hline F-Stat, Instrument & 215 & 57 & 83 & 27 \\
\hline Hansen J p-value (Overid Test) & 0.321 & 0.261 & 0.021 & 0.242 \\
\hline
\end{tabular}

Reported values are the estimated marginal effects with robust standard errors clustered at the country-sector level in brackets. $* * * \mathrm{p}<0.01, * * \mathrm{p}<0.05, * \mathrm{p}<0.1$. The dependent variable in Columnns $1-2$ is a binary variable that indicates whether a firm exports. The dependent variable in Columns 3-4 is a binary variable that indicates whether a firm indirectly exports, conditional on them exporting. The first stage F-Stat and Hansen J p-value come from a linear IV regression model since these statistics are not normally reported in IV Probit specifications. Total Bribes is a the sum of the component binary bribe variables. 
Table 7

Impact of Corruption on Firm Profits (OLS)

\begin{tabular}{lcccc}
\hline & Domestic Firms & Indirect Export Firms & Direct Export Firms \\
\hline \multirow{3}{*}{ Corruption } & $(1)$ & $(2)$ & $(3)$ \\
& & & \\
Controls & 0.001 & -0.031 & $-0.035^{* *}$ \\
Country FE & {$[0.007]$} & {$[0.025]$} & {$[0.014]$} \\
Sector FE & Yes & Yes & Yes \\
Year FE & Yes & Yes & Yes \\
& Yes & Yes & Yes \\
Observations & Yes & Yes & Yes \\
R-squared & & & 4,405 \\
\hline
\end{tabular}

Robust standard errors clustered at the country-sector level in brackets. $* * * \mathrm{p}<0.01, * * \mathrm{p}<0.05$, * $\mathrm{p}<0.1$. In column (1), the dependent variable is the ln of domestic profits for domestic firms. In column (2), the dependent variable is the ln of domestic and export profits of indirect exporting firms. In column (3), the dependent variable is the ln of domestic and export profits of direct exporting firms. 
Table 8

Impact of Corruption on Firm Selection into Export Markets - Sensitivity Analys is (Probit)

\begin{tabular}{|c|c|c|c|c|c|c|c|c|}
\hline & \multicolumn{4}{|c|}{ Export Dummy } & \multicolumn{4}{|c|}{ Indirect Export Dummy (conditional on exporting) } \\
\hline & (1) & (2) & (3) & (4) & (5) & (6) & $(7)$ & $(8)$ \\
\hline Corruption & $\begin{array}{c}0.005^{* *} \\
{[0.002]}\end{array}$ & $\begin{array}{c}0.006^{* *} \\
{[0.002]}\end{array}$ & $\begin{array}{c}0.008 * * * \\
{[0.003]}\end{array}$ & & $\begin{array}{c}0.009 * * \\
{[0.004]}\end{array}$ & $\begin{array}{c}0.010 * * \\
{[0.005]}\end{array}$ & $\begin{array}{c}0.012 * * \\
{[0.005]}\end{array}$ & \\
\hline Corrupt 1 & & & & $\begin{array}{c}0.014 \\
{[0.009]}\end{array}$ & & & & $\begin{array}{c}0.012 \\
{[0.016]}\end{array}$ \\
\hline Corrupt 2 & & & & $\begin{array}{c}0.014 \\
{[0.011]}\end{array}$ & & & & $\begin{array}{c}-0.002 \\
{[0.019]}\end{array}$ \\
\hline Corrupt 3 & & & & $\begin{array}{c}0.024 * * \\
{[0.009]}\end{array}$ & & & & $\begin{array}{c}0.047 * * * \\
{[0.018]}\end{array}$ \\
\hline Corrupt 4 & & & & $\begin{array}{c}0.024 * * \\
{[0.010]}\end{array}$ & & & & $\begin{array}{c}0.045^{* * *} \\
{[0.017]}\end{array}$ \\
\hline ln (Productivity) & $\begin{array}{c}0.040 * * * \\
{[0.004]}\end{array}$ & $\begin{array}{c}0.041 * * * \\
{[0.004]}\end{array}$ & & $\begin{array}{c}0.037 * * * \\
{[0.003]}\end{array}$ & $\begin{array}{c}-0.044 * * * \\
{[0.006]}\end{array}$ & $\begin{array}{c}-0.045^{* * *} * \\
{[0.006]}\end{array}$ & & $\begin{array}{c}-0.040 * * * \\
{[0.005]}\end{array}$ \\
\hline $\ln (\mathrm{TFP})$ & & & $\begin{array}{c}0.022 * * * \\
{[0.005]}\end{array}$ & & & & $\begin{array}{c}-0.023^{* *} \\
{[0.011]}\end{array}$ & \\
\hline Other Controls & Yes & Yes & Yes & Yes & Yes & Yes & Yes & Yes \\
\hline Country FE & No & No & Yes & Yes & No & No & Yes & Yes \\
\hline Sector FE & No & No & Yes & Yes & No & No & Yes & Yes \\
\hline Year FE & No & No & Yes & Yes & No & No & Yes & Yes \\
\hline Country* Year FE & Yes & No & No & No & Yes & No & No & No \\
\hline Sector* Year FE & Yes & No & No & No & Yes & No & No & No \\
\hline Country*Sector FE & Yes & No & No & No & Yes & No & No & No \\
\hline Country*Sector*Year FE & No & Yes & No & No & No & Yes & No & No \\
\hline Observations & 22,956 & 22,809 & 16,445 & 23,317 & 5,843 & 5,798 & 4,392 & 6,111 \\
\hline $\begin{array}{l}\text { Reported values are the es } \\
\text { The dependent variable in } \\
\text { variable that indicates whe } \\
\text { include country*industry } \\
\text { measures are now dummy } \\
\text { Corruption } 1 \text { is "A Minor } \\
\text { Obstacle." }\end{array}$ & $\begin{array}{l}\text { mated marg } \\
\text { olumnns (1 } \\
\text { her a firm in } \\
\text { ear FE, and } \\
\text { ariables ind } \\
\text { stacle", Co }\end{array}$ & $\begin{array}{l}\text { fects with } \\
\text { binary va } \\
\text { y exports, } \\
\text { ans } 3 \text { and } 7 \\
\text { how mucl } \\
\text { on } 2 \text { is "A }\end{array}$ & $\begin{array}{l}\text { standard e } \\
\text { hat indicat } \\
\text { ional on the } \\
\text { FP instead } \\
\text { obstacle c } \\
\text { cate Obstac }\end{array}$ & $\begin{array}{l}\text { lustered at } \\
\text { ether a firm } \\
\text { orting. Col } \\
\text { s per empl } \\
\text { ion is for th } \\
\text { rruption } 3\end{array}$ & $\begin{array}{l}\text { ountry-sect } \\
\text { ts. The dep } \\
1 \text { and } 5 \text { inc } \\
\text { o measure } \\
\text { Corruptio } \\
\text { Major Obs }\end{array}$ & $\begin{array}{l}\text { el in bracke } \\
\text { nt variable i } \\
\text { air interacti } \\
\text { ctivity. Fina } \\
\text { he excluded } \\
\text { and Corrup }\end{array}$ & $\begin{array}{l}* \mathrm{p}<0.01 \text {, } \\
\text { imnns }(5- \\
\text { the FE, } \\
\text { lumns } 4 \text { a } \\
\text { is "No } \\
\text { is "A Ve }\end{array}$ & $\begin{array}{l}.05, * \mathrm{p}<0.1 . \\
\text { inary } \\
2 \text { and } 6 \\
\text { e corruption } \\
\text { e", } \\
\text { re }\end{array}$ \\
\hline
\end{tabular}




\section{Appendix}

\subsection{Domestic Profits}

Firms that sell domestically face the following profit maximizing decision (where subscript $\mathrm{j}$ is dropped since profits depend on productivity and not the identity of the firm):

$\max \pi_{d}=p x-\frac{c}{\theta} x-c f_{d}$

or

$\max \pi_{d}=A p^{1-\varepsilon}-\frac{c}{\theta} A p^{-\varepsilon}-c f_{d} \quad$ since $x=A p^{-\varepsilon}$.

Taking the first order condition of this profit function with respect to $p$ yields:

$(1-\varepsilon) A p^{-\varepsilon}-\varepsilon \frac{c}{\theta} A p^{-\varepsilon-1}=0$

or

$p=\frac{c}{\theta} \frac{\varepsilon}{\varepsilon-1}$

or

$p=\frac{c}{\theta \alpha} \quad$ since $\varepsilon=\frac{1}{1-\alpha}$.

Plugging this price back into the firm's demand function generates the optimal output: $x=c^{-\varepsilon} \alpha^{\varepsilon} A \theta^{\varepsilon}$.

Finally, plugging the optimal output and price back in the profit function gives:

$\pi_{d}=\left(p-\frac{c}{\theta}\right) x-c f_{d}$

$\pi_{d}=\left(\frac{c}{\theta \alpha}-\frac{c}{\theta}\right)\left(c^{-\varepsilon} \alpha^{\varepsilon} A \theta^{\varepsilon}\right)-c f_{d}$

$\pi_{d}=\theta^{\varepsilon-1}(1-\alpha) A\left(\frac{c}{\alpha}\right)^{1-\varepsilon}-c f_{d}$

or

(1) $\pi_{d}=\Theta B-c f_{d}$

where $\Theta=\theta^{\varepsilon-1}$ and $B=(1-\alpha) A\left(\frac{c}{\alpha}\right)^{1-\varepsilon}$.

\subsection{Direct Exporting}

In addition to selling domestically, a firm may also wish to export directly abroad. This will generate the following profit maximizing decision:

$\max \pi_{x}=p x-\frac{c}{\theta} \tau_{x} x-c f_{x}$ 
or

$\max \pi_{x}=A p^{1-\varepsilon}-\frac{c}{\theta} \tau_{x} A p^{-\varepsilon}-c f_{d} \quad$ since $x=A p^{-\varepsilon}$

where $\tau_{x}$ represent variable trade costs and $c f_{x}$ are additional fixed in order to sell directly abroad. Note that firms have already paid the fixed cost $c f_{d}$ to produce and sell domestically and are thus now faced with the decision of whether to also export directly.

Taking the first order condition, solving for the optimal price and quantity, and plugging these values back into the profit function yields:

$$
\begin{aligned}
& \pi_{x}=\left(\frac{\tau_{x} c}{\theta \alpha}-\frac{\tau_{x} c}{\theta}\right)\left(\tau_{x}^{-\varepsilon} c^{-\varepsilon} \alpha^{\varepsilon} A \theta^{\varepsilon}\right)-c f_{x} \\
& \pi_{x}=\tau_{x}^{1-\varepsilon} \theta^{\varepsilon-1}(1-\alpha) A\left(\frac{c}{\alpha}\right)^{1-\varepsilon}-c f_{x}
\end{aligned}
$$

or

(2) $\pi_{x}=\tau_{x}^{1-\varepsilon} \Theta B-c f_{x}$.

\subsection{Indirect Exporting}

In addition to selling domestically but instead of directly exporting, a firm may wish to export indirectly through an intermediate. This will generate the following profit maximizing decision:

$\max \pi_{i}=p x-\frac{c}{\theta} \tau_{i} x-c f_{i}$

or

$\max \pi_{i}=A p^{1-\varepsilon}-\frac{c}{\theta} \tau_{i} A p^{-\varepsilon}-c f_{i} \quad$ since $x=A p^{-\varepsilon}$

where $\tau_{i}$ represent variable trade costs associated with indirectly exporting and $c f_{i}$ are additional fixed in order to indirectly export. Relative to directly exporting, it is assumed that the variable costs of indirectly exporting are higher $\left(\tau_{i}>\tau_{x}\right)$ but the fixed costs associated with indirectly exporting are lower $\left(f_{i}<f_{x}\right)$.

Taking the first order condition, solving for the optimal price and quantity, and plugging these values back into the profit function yields:

$$
\begin{aligned}
& \pi_{i}=\left(\frac{\tau_{i} c}{\theta \alpha}-\frac{\tau_{i} c}{\theta}\right)\left(\tau_{i}^{-\varepsilon} c^{-\varepsilon} \alpha^{\varepsilon} A \theta^{\varepsilon}\right)-c f_{i} \\
& \pi_{i}=\tau_{i}^{1-\varepsilon} \theta^{\varepsilon-1}(1-\alpha) A\left(\frac{c}{\alpha}\right)^{1-\varepsilon}-c f_{i}
\end{aligned}
$$

or 
(3) $\pi_{i}=\tau_{i}^{1-\varepsilon} \Theta B-c f_{i}$.

\subsection{Fixed Cost of Corruption}

Instead of imposing an additional variable cost of production, suppose that corruption leads to an additional fixed cost of production $\left(c f_{c}\right)$ for domestic firms and direct exporting firms. Thus, corruption leads to the following profits from domestic sales:

$$
\pi_{d}^{\prime}=\Theta B-c f_{d}-c f_{c}
$$

and the following profits from direct exports:

$$
\pi_{x}^{\prime}=\tau_{x}^{1-\varepsilon} \Theta B-c f_{x}-c f_{c}
$$

Again, the profits $\left(\pi_{i}\right)$ from indirectly exporting are unaffected. Figure A1 shows a graphical representation of these profit curves when corruption imposes a fixed cost on firms. ${ }^{25}$

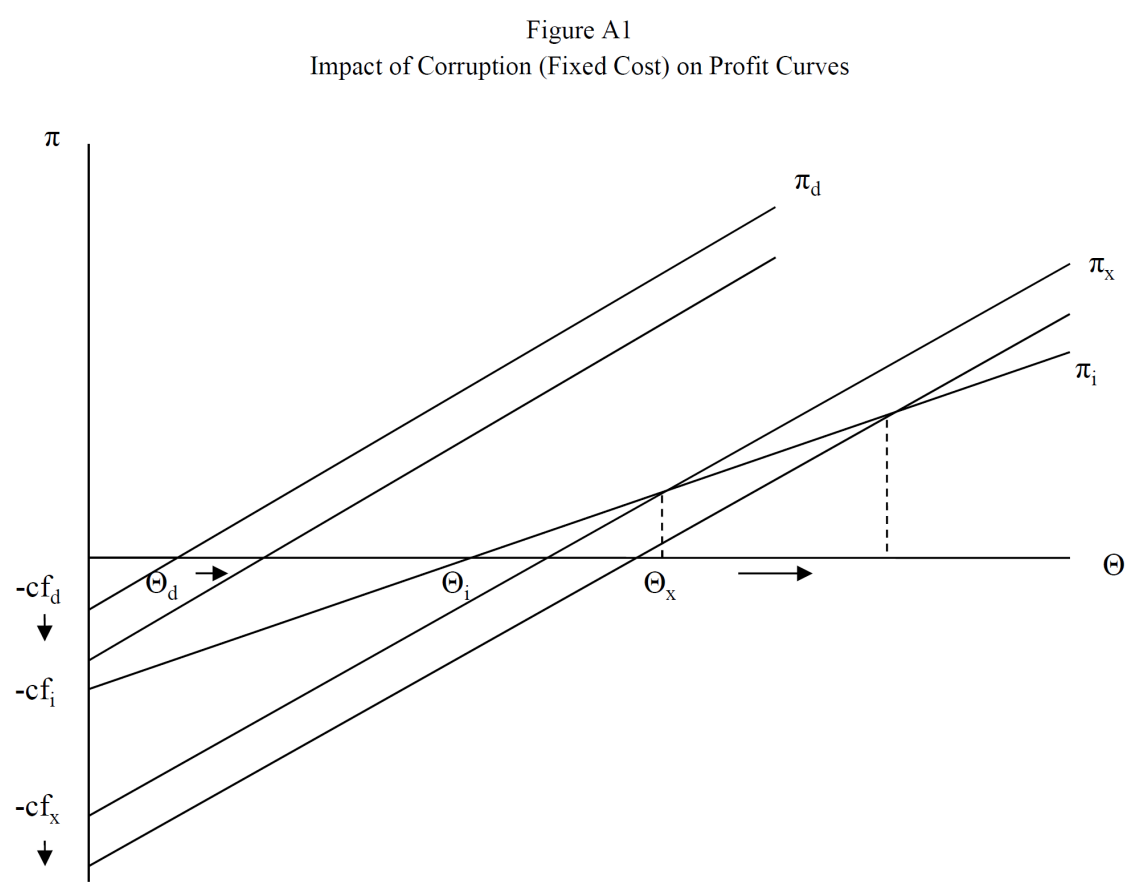

\footnotetext{
${ }^{25}$ Figure A1 assumes that $f_{d}+f_{c}<\tau_{i}^{\varepsilon-1} f_{i}<\tau_{x}^{\varepsilon-1}\left(f_{x}+f_{c}\right)$ which ensures that the ordering $\Theta_{d}<\Theta_{i}<\Theta_{x}$ remains the same.
} 
As we see in Figure A1, the profit curves associated with domestic sales and with direct exports both shift down. Therefore, corruption increases the entrance productivity cutoff $\left(\Theta_{d}\right)$ and the direct export productivity cutoff $\left(\Theta_{x}\right)$ but leaves the indirect export productivity cutoff $\left(\Theta_{i}\right)$ unchanged. This setup generates the same qualitative predictions outlined in Figure 3 and in Propositions 2 and 3. As a result, for the purposes of this paper it is not crucially important whether corruption is modeled as a fixed cost or a variable cost.

\subsection{Additional IV Results}

In addition to the results reported in Table 6, this section pursues a variety of other IV Probit approaches. First, rather than using "Total Bribes" as an instrument (as in columns 1 and 3 of Table 6), a binary variable called "Any Bribes" is created that equals one if the firm was bribed at least once. Second, rather than using the bribe components together (as in columns 2 and 4 of Table 6), each component is used separately as an instrument. Third, the Enterprise Survey provides an assortment of other variables that are potentially useful as instruments. For instance, there are questions about whether "it is common to pay informal payments/gifts to get things done?" "what percent of total senior management's time was spent on dealing with requirements imposed by government regulation?" "what percent of the contract value would be typically paid in informal payments or gifts to secure contract?" and "what percent of total annual sales are paid in informal payments?" Despite the poor coverage of these variables, they are used as instruments in the analysis that follows.

Table A1 reports the IV Probit results using the export dummy as the dependent variable while Table A2 uses the indirect export dummy as the dependent variable. The top panel in each table reports the second stage results, while the bottom panels report the first stage results. 
Table A 1

Impact of Corruption on Firm Selection into Export Markets (Alternate IV Probit Results)

\begin{tabular}{|c|c|c|c|c|c|c|c|c|c|c|c|c|c|}
\hline & \multicolumn{13}{|c|}{ Export Dummy } \\
\hline & (1) & (2) & (3) & (4) & (5) & (6) & (7) & (8) & (9) & (10) & (11) & (12) & (13) \\
\hline \multirow[t]{2}{*}{ Corruption } & $0.060 * * *$ & $0.058 * * *$ & 0.033 & 0.039 & $0.053^{*}$ & $0.062 * * *$ & $0.045^{* *}$ & $0.090 * * *$ & $0.051 * *$ & $0.043^{* *}$ & 0.016 & 0.023 & 0.002 \\
\hline & [0.014] & {$[0.014]$} & [0.026] & {$[0.031]$} & [0.031] & {$[0.024]$} & {$[0.018]$} & [0.031] & {$[0.021]$} & {$[0.021]$} & {$[0.027]$} & {$[0.000]$} & {$[0.021]$} \\
\hline Controls & Yes & Yes & Yes & Yes & Yes & Yes & Yes & Yes & Yes & Yes & Yes & Yes & Yes \\
\hline Country FE & Yes & Yes & Yes & Yes & Yes & Yes & Yes & Yes & Yes & Yes & Yes & Yes & Yes \\
\hline Sector FE & Yes & Yes & Yes & Yes & Yes & Yes & Yes & Yes & Yes & Yes & Yes & Yes & Yes \\
\hline Year FE & Yes & Yes & Yes & Yes & Yes & Yes & Yes & Yes & Yes & Yes & Yes & Yes & Yes \\
\hline Observations & 23,316 & 23,316 & 23,150 & 22,441 & 23,188 & 23,106 & 22,874 & 23,065 & 23,017 & 7,607 & 22,429 & 8,176 & 15,128 \\
\hline
\end{tabular}

First Stage IV Probit Results:

Mean Corruption

Total Bribes

Any Bribes

Electrical Bribes

Water Bribes

Telephone Bribes

Construction Bribes

Tax Official Bribes

Import License Bribes

Operating License Bribes

Bribes to Get Things Done

Time on Gov Regulation

Bribe to Contract Ratio

Bribe to Sales Ratio

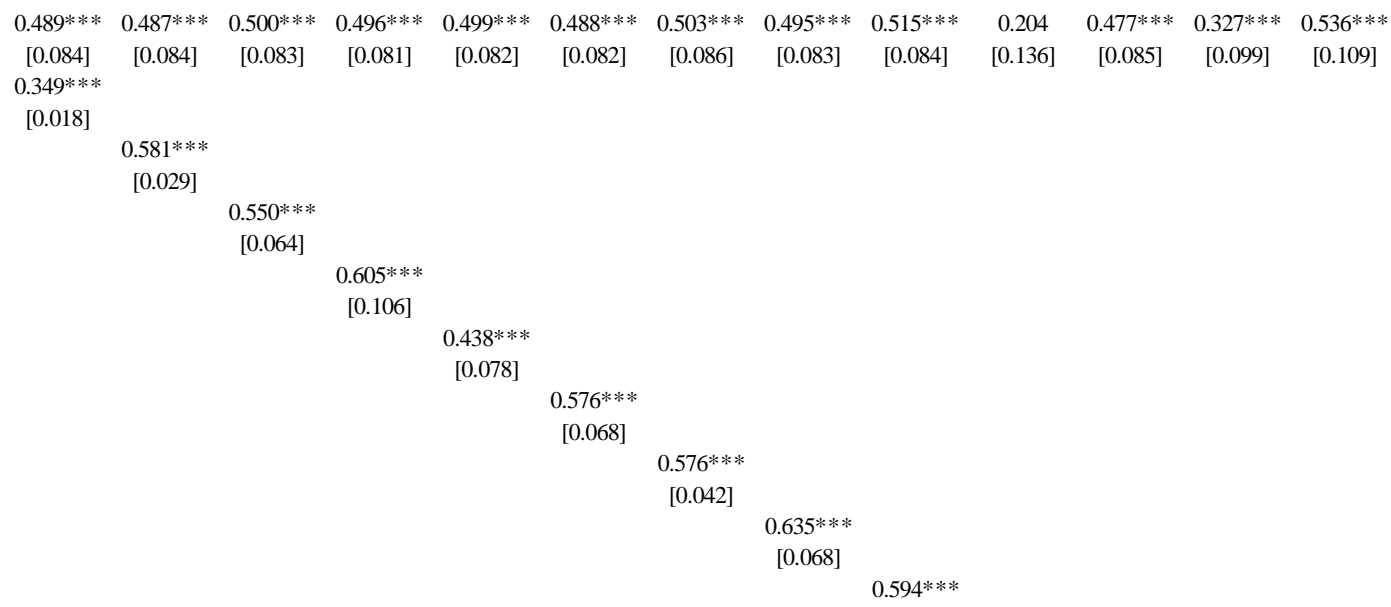

$\begin{array}{llllllllllll}\text { F-Stat, Instrument } & 215 & 239 & 53 & 32 & 44 & 56 & 122 & 55 & 115 & 56 & 32\end{array}$

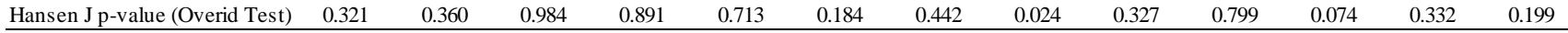

Reported values are the estimated marginal effects with robust standard errors clustered at the country-sector level in brackets. $* * * \mathrm{p}<0.01, * * \mathrm{p}<0.05, * \mathrm{p}<0.1$. 
Table A2

Impact of Corruption on Firm Selection into Export Markets (Alternate IV Probit Results)

\begin{tabular}{|c|c|c|c|c|c|c|c|c|c|c|c|c|c|}
\hline & \multicolumn{13}{|c|}{ Indirect Export Dummy (conditional on exporting) } \\
\hline & (1) & (2) & (3) & (4) & (5) & (6) & (7) & $(8)$ & (9) & (10) & (11) & (12) & (13) \\
\hline Corruption & $\begin{array}{c}0.068^{* * * *} \\
{[0.024]}\end{array}$ & $\begin{array}{c}0.078^{* * *} * \\
{[0.026]}\end{array}$ & $\begin{array}{c}0.065 \\
{[0.051]}\end{array}$ & $\begin{array}{c}0.184 * * * \\
{[0.071]}\end{array}$ & $\begin{array}{c}0.173^{* * *} \\
{[0.056]}\end{array}$ & $\begin{array}{c}0.057 \\
{[0.052]}\end{array}$ & $\begin{array}{c}0.085^{* * * *} \\
{[0.031]}\end{array}$ & $\begin{array}{l}0.089^{*} \\
{[0.052]}\end{array}$ & $\begin{array}{c}0.136 * * * * \\
{[0.037]}\end{array}$ & $\begin{array}{c}0.006 \\
{[0.043]}\end{array}$ & $\begin{array}{c}0.006 \\
{[0.000]}\end{array}$ & $\begin{array}{c}0.175^{* *} \\
{[0.083]}\end{array}$ & $\begin{array}{c}0.161^{* *} \\
{[0.078]}\end{array}$ \\
\hline Controls & Yes & Yes & Yes & Yes & Yes & Yes & Yes & Yes & Yes & Yes & Yes & Yes & Yes \\
\hline Country FE & Yes & Yes & Yes & Yes & Yes & Yes & Yes & Yes & Yes & Yes & Yes & Yes & Yes \\
\hline Sector FE & Yes & Yes & Yes & Yes & Yes & Yes & Yes & Yes & Yes & Yes & Yes & Yes & Yes \\
\hline Year FE & Yes & Yes & Yes & Yes & Yes & Yes & Yes & Yes & Yes & Yes & Yes & Yes & Yes \\
\hline Observations & 6,111 & 6,111 & 6,051 & 5,907 & 6,073 & 6,025 & 5,981 & 5,993 & 6,015 & 1,817 & 5,874 & 1,885 & 3,798 \\
\hline First Stage IV Probit Results: & & & & & & & & & & & & & \\
\hline Mean Corruption & $\begin{array}{c}0.277^{* *} \\
{[0.115]}\end{array}$ & $\begin{array}{c}0.253 * * \\
{[0.112]}\end{array}$ & $\begin{array}{c}0.253^{* *} \\
{[0.110]}\end{array}$ & $\begin{array}{c}0.274^{* *} \\
{[0.113]}\end{array}$ & $\begin{array}{c}0.256^{* *} \\
{[0.111]}\end{array}$ & $\begin{array}{c}0.242 * * \\
{[0.113]}\end{array}$ & $\begin{array}{c}0.260^{* *} \\
{[0.112]}\end{array}$ & $\begin{array}{c}0.263^{* *} \\
{[0.109]}\end{array}$ & $\begin{array}{c}0.264 * * \\
{[0.114]}\end{array}$ & $\begin{array}{c}0.246 \\
{[0.214]}\end{array}$ & $\begin{array}{c}0.234 * * \\
{[0.115]}\end{array}$ & $\begin{array}{c}0.362^{* *} \\
{[0.152]}\end{array}$ & $\begin{array}{l}0.213^{*} \\
{[0.113]}\end{array}$ \\
\hline Total Bribes & $\begin{array}{c}0.381 * * * \\
{[0.031]}\end{array}$ & & & & & & & & & & & & \\
\hline Any Bribes & & $\begin{array}{c}0.653^{* * * *} \\
{[0.050]}\end{array}$ & & & & & & & & & & & \\
\hline Electrical Bribes & & & $\begin{array}{c}0.829 * * * \\
{[0.129]}\end{array}$ & & & & & & & & & & \\
\hline Water Bribes & & & & $\begin{array}{l}0.360^{*} \\
{[0.215]}\end{array}$ & & & & & & & & & \\
\hline Telephone Bribes & & & & & $\begin{array}{c}0.518^{* * * *} \\
{[0.156]}\end{array}$ & & & & & & & & \\
\hline Construction Bribes & & & & & & $\begin{array}{c}0.643^{* * * *} \\
{[0.091]}\end{array}$ & & & & & & & \\
\hline Tax Official Bribes & & & & & & & $\begin{array}{c}0.660^{* * * *} \\
{[0.065]}\end{array}$ & & & & & & \\
\hline Import License Bribes & & & & & & & & $\begin{array}{c}0.613^{* * * *} \\
{[0.120]}\end{array}$ & & & & & \\
\hline Operating License Bribes & & & & & & & & & $\begin{array}{c}0.632 * * * * \\
{[0.083]}\end{array}$ & & & & \\
\hline Bribes to Get Things Done & & & & & & & & & & $\begin{array}{c}0.208^{* * * *} \\
{[0.039]}\end{array}$ & & & \\
\hline Time on Gov Regulation & & & & & & & & & & & $\begin{array}{c}0.006^{* * * *} \\
{[0.001]}\end{array}$ & & \\
\hline Bribe to Contract Ratio & & & & & & & & & & & & $\begin{array}{l}0.008^{*} \\
{[0.005]}\end{array}$ & \\
\hline Bribe to Sales Ratio & & & & & & & & & & & & & $\begin{array}{c}0.023^{* * * *} \\
{[0.007]}\end{array}$ \\
\hline F-Stat, Instrument & 83 & 90 & 25 & 4 & 9 & 30 & 54 & 16 & 32 & 15 & 12 & 5 & 8 \\
\hline Hansen J p-value (Overid Test) & 0.021 & 0.026 & 0.019 & 0.218 & 0.324 & 0.005 & 0.068 & 0.042 & 0.218 & 0.358 & 0.011 & 0.117 & 0.904 \\
\hline
\end{tabular}

Column 1 in each of these tables re-reports the results from columns 1 and 3 in Table 6. Column 2 uses the "Any Bribes" variable and columns 3-9 use the individual bribe variables separately as instruments. Finally, columns 10-13 try the other measures provided by the Enterprise Survey as instruments. Not surprisingly, the sample sizes vary enormously and the strength of the first stages differ across these specifications. However, corruption has a positive effect in every column in Tables A1 and A2, and this coefficient is significant in the majority of specifications. 